УДК 2-11

\title{
From a Neo-Patristic Legacy of Georges Florovsky to the Radical Theological Commitment in the Dialogue with Science
}

\author{
Alexei V. Nesteruk* \\ University of Portsmouth, UK \\ Lion Gate Building, Lion Terrace, \\ Portsmouth, PO1 $3 \mathrm{HF}$
}

Received 09.04.2016, received in revised form 11.07.2016, accepted 24.08.2016

\begin{abstract}
The article discusses the possible ways of the dialogue between science and theology in the context of modern atheism and secularism. It is argued that the dialogue cannot be symmetric and that the task of a theological critique of secularism is extended to the critical analysis of modern scientific theories in the context of existential problems of humankind, as well as of any particular person. As a matter of a historical precedent one discusses an idea of a neopatristic synthesis in theology advanced by a famous Russian philosopher and theologian Fr. George Florovsky. The paper discusses a possibility of extending of a neopatristic ethos towards the dialogue between theology and science. One then accentuates the main problems of the dialogue such as the centrality of human person and primacy of existential faith as being the basis for a scientific creativity. Any tension between theology and science is destined to disappear if they both are seen as flourishing from the same human experience of existence-communion. Science thus cannot be detached from theology and it is in a complex with theology that it can be properly understood and treated.
\end{abstract}

Keywords: atheism, neo-patristic synthesis, person, science, secularism, theology, radical theological commitment, knowledge.

DOI: 10.17516/1997-1370-2016-9-9-2150-2183.

Research area: philology.

\section{Introduction:}

"Theological commitment"

in the dialogue between theology and science

Research related to the dialogue between theology and science became a matter of intensive scholarly discussions in the last 20-30 years. It is then natural to ask whether this dialogue achieved any results which had impact on both science and theology. A negative answer is provided by the unceasing scientific and technological advance (in particular in the exact natural sciences) which continues with no recourse to the dialogue between theology and science whatsoever. All discussions on whether science and theology are in conflict, or in "peaceful coexistence" with each other, do not have existential implications: the problem remains and its ongoing presence points

(C) Siberian Federal University. All rights reserved

* Corresponding author E-mail address: alexei.nesteruk@port.ac.uk 
to something which is basic and unavoidable in the very human condition. This result indicates that the method of conducting this dialogue at present is unsatisfactory in the sense that it does not address the major question as to what is the underlying foundation in the very distinction, difference and division between science and religion as those modes of activity and knowledge which flourish from one and the same human subjectivity. But this type of questioning makes any scientific insight irrelevant simply because science is not capable of dealing with the question of its own facticity, that is the facticity of that consciousness which is the "pillar and ground" of science. Theology can respond to this question from within the explicitly belief-based ground, namely faith in that the knowledge of the world represents natural revelation accessible to humanity because of God-given faculties. Knowledge is possible only by human persons whose basic qualities are freedom and capacity to retain transcendence with respect to all they assimilate through life and knowledge. In this sense the universe as articulated reality has existence and sense only in a mode of personhood, which is a divine gift. Since science does not account for the very possibility of knowledge, that is personhood, it is automatically prevented from participation in the dialogue with theology on equal footing. If there is no impact of this "dialogue" on logic and development of science, what remains for theology is to exercise an introspection upon science, to conduct a certain critique of science from a position which is beyond not only scientific thinking, but secular thinking in general related to particular socio-historical and economic realities. Thus symmetry between theology and science is broken from its very inception and constitutes that approach to the science-religion discussions which we describe in terms of theological commitment, a stance on human being which always positions it above and beyond those realities which are disclosed by science alone. It appeals to those meanings of existence which do not compel the recognition of science in the manner of natural phenomena. These meanings originate in an innate quality of human beings to long for immortality, that is communion with the unconditional personal ground of the whole world, which humanity names God. It is through this longing that the universe acquires a certain sense as that constituent of God's creation which makes it possible for human persons to fulfil God's promise for eternal life and communion. Theological commitment is thus existential commitment. ${ }^{1}$

Another aspect of theological commitment in the dialogue is the reaction to modern atheism. ${ }^{2}$ Indeed, in its goals and tasks the dialogue between Christianity and science is to oppose atheism. ${ }^{3}$ However, if one carefully looks at how this dialogue has been conducted so far, one easily realises that the existing forms of this dialogue are adapted to that which is imposed by atheism. Contemporary atheism manifests itself not only as freedom from historical authorities and tradition (that is the liberation from freedom in a Christian sense) or as the unprincipled following of the proclamation "enjoy life for there is no God", but as the worst form of the unenlightened slavery of the Plato's cave in which the signs of the Divine presence are not recognised and the very ability to see them in the world is reduced to nothing. Atheism promotes a cult of immanence, the actually existent infinity of the given ${ }^{4}$, appealing de facto to deprivation of the senses and the vision of the transcendent (and hence to the relaxation of a soteriological moment). Since modern science, and technology in particular, encourage individuals to be transcendent-blind, creating the immanent images of the transcendent, the advocates of atheism appeal to science and in so doing atheism adjusts to the demands and moods of modern time. It is much easier not to 
deny the presence of the Divine in the world, but to claim that all spheres of the human activity are self-sufficient and do not need any reference to God. Since from a philosophical point of view the question of God's existence or nonexistence cannot be decided (the philosophical mind remains in the "negative certitude" with respect to this question), then would be easier to recognise that science, art, literature etc. are just given in rubrics of that which is unconcealed to humanity. Here atheism reveals itself as secularism, as a kind of trans-ideological läicité , as a servility to nobody's interests, and to the alleged ideal of humanity understood only empirically, as that humanity which is alive here and now ${ }^{5}$ (it is supposed that this ideal of humanity has in itself a universal criterion of its own definition). To define this humanity in simple categories which overcome racial national and class differences one needs a universal language. It is science which pretends to be such a language; to be more precise, it is that scientific form of thinking which reduces the phenomenon of humanity in all its various manifestations to the physical and biological. It is clear that modern atheism as a certain form of the "immanent humanism" is no more than a scientific atheism. However this atheism positions itself as more aggressive ${ }^{6}$ and sinister, more advanced philosophically and antitheologically ${ }^{7}$ than was the case, for example, in Soviet Russia. The reason for this is that modern atheism is ultimately motivated by the logic of material production and human resources, that is by the needs of the developing economies and not an abstract ideology. ${ }^{8}$

The freedom from traditional and philosophical authorities as well as historical values inverts in modern atheism towards slavery to the scientifically articulated and verified. It is paradoxical, and fundamentally different from the former Soviet model of atheism, that a slogan that "knowledge is power" is not appreciated in the economically advanced societies, for allencompassing knowledge is potentially socially dangerous. This entails in turn that knowledge and science both function in society in a reduced and popular form which does not allow one to judge of its certitude, quality and completeness. Scientific knowledge becomes a world-outlook, ideology and a filter of the social loyalty and adequacy. As a result the abuse of science becomes a norm which creates an illusion of its efficiency and truth in all spheres of life. The scientific method is treated as self-sufficient and not being in need of any justification and evaluation. Science proclaims the truth of the world from its own rationality which functions in the disincarnate collective consciousness. Supported through the system of grants from the economically powerful groups, it is allegedly done for the sake of human good. However by functioning in society science forgets about the simple truth that science is a human creation and its initial meaning was to guard the interests of people and not to make them slaves and hostages of the scientific method.

The situation with the dominance of the scientific approach to all aspects of life becomes even more paradoxical when one realises that human beings do not become more happy and free from the aspects of material existence. They cannot escape social injustice, hardship of mundane life, diseases and moral losses. This happens because science as an ideology does not spell out what is most important, namely that it does not know the goals and ways of its future development. In its grandeur science has to intentionally disregard those aspects of reality which are not described by it or which behave sporadically and unpredictably with respect to scientific prognosis. Economic growth and welfare of the developed nations which used to live in comfortable conditions, the cult of consumption and greed, demand more technological development related to the exploitation of the natural resources. 
Every new discovery in physics is employed for the optimisation of the production of goods and energy, so that one can speak about merciless exploitation of physical reality in general. It is very seldom that the question of the legitimacy and justification of such an exploitation, or, as some say, "rape of nature" is raised. By making nature an object of manipulation scientific consciousness forgets humanitarian duties in respect to nature: nature must be "respected" simply because we live in it and that there is the light of that all-embracing reason (Logos) which we, human beings, carry in ourselves as little logoi. The objects of nature are inseparable from their creator, so that the oblivion of this fact leads to the loss of love of them in the same sense as the loss of love for other people. A careful insight of a philosopher or a theologian will unmistakenly identify the root of the problem, namely that the atomisation, and disassemblement of the physical reality in course of its exploitation has it origin in the ethical individualism of those who know this reality, that is the loss of love of nature in the scientific community. The individualism consists in that the exploration and acquisition of physical reality becomes an affair of that human spirit which is divided in its narrow professional and corporative interests in which the element of catholicity with nature, through the divine-given existence, is forgotten because love does not rule anymore for the interest of knowledge and longing for the perpetual good.

The ambitions of the immanent secular reason, supported by the scientific achievements seem to be even more strange if one realises that modern science, in spite of its successes manifests the symptoms of a deep crisis related to the uncertainty of its goals. Scientific activity is purposive to the extent which accompanies any human activity. Any particular research has a concrete objective either to satisfy a practical interest or simply curiosity. However when we speak of the uncertainty of goals of science in general, we mean something different: scientific quest is spontaneous and is not related to the spiritual, infinite tasks of humanity. The practical purposiveness of scientific research thus unfolds only a particular sector of nature so that there remains a gap between that which has been known through a scientific phenomenalisation and that which cannot be known by science at all. This fact manifests that nature has a propensity to remain concealed and react to human experiments unpredictably. As an example, one can point to nuclear physics which, by acquiring the mysteries of the microworld risks creating a state of matter which can threaten human existence on this planet. ${ }^{10}$ There is a danger in nuclear experiments of trespassing the boundary of the unconcealed, related to human existence, when constructed devices and artificial states of matter may behave in a non-human way, contradicting the initial objectives of experiments and turning science against humanity. A simple example from philosophical discussions of the 1950s is the atomic bomb which brought humanity to a new situation when the conditions of its existence are not controlled anymore only by the natural processes, but depend on the good will of people making decisions of using or not nuclear weapons, thus influencing global natural processes. ${ }^{11}$ Another example is the ecological crisis. The melting polar cap of Greenland, extinction of some animal species and forthcoming migration of peoples living in the Arctic region show that technological applications of science escaping moral reason lead to problems of the social and political order. Science through technology is not neutral anymore to economics and politics and, on the contrary, becomes their result and prophet. The process of exploration and knowledge of the surrounding world and thus its "transformation" becomes involved into the spheres of interest of the world's powers 
and classes so that its ethical significance is determined by its belonging to this or that socio-economic demand. That which has been said entails that scientific knowledge and the very idea that society can and must develop only on the basis of scientific progress becomes an ideological dogma, the following and defending of which in turn becomes a matter of social loyalty. However, without understanding its logic and definite goals, scientific progress, being de facto unavoidable and irreversible, carries in itself a potential danger because of the unpredictable nature of it applications. Human beings want to live better and longer; however this natural desire does not supply a clear understanding of the goals of science, whereas humanity becomes more and more dependent on its achievements and applications.

The fact that scientific advance leaves huge realms of being unexplored and unknown becomes even more evident in theoretical sciences, in particular in cosmology. On the one hand cosmology provides us with a comprehensive theory of the universe supported by observations. On the other hand it has to admit that those forms of matter in the universe which are physically understood constitute only $4 \%$ of its material content (the remaining 96\% associated with the so called dark mass and dark energy remain up to now beyond the reach of experiments; their existence is a matter of theoretical conviction). The more cosmology refines its scenario of the universe's evolution, the more it realises the abyss of the physically unknown. Speaking philosophically, cosmology makes clearly seen the boundaries of the unconcealed which is related to humanity: it is only $4 \%$ of mater in the universe which can be said to be consubstantial to human physical and biological form. However, in spite of all evidence for the limited nature of our knowledge of the universe, cosmologists sometimes position themselves as "prophets and priests" of the universe, preaching of it as if they know the absolute truth of the world.

One of the major attributes of modern science which makes it powerful is its radical mathematization of nature. Physics and cosmology, through mathematical models and theories, predicate realities inaccessible in direct experiments. There is a paradoxical shift of representations of reality here: unobservable intelligibleentities are treated as more fundamental and responsible for the contingent display of visible nature. As we argued elsewher (Nesteruk 2008, pp. 188-205) mathematisation of nature is accompanied by the diminution of humanity, in particular the personal dimension of existence. Person disappears from scientific discourse in spite of the fact that all articulated facts are made by persons. Science is being effected in the name of human persons, but this same person turns out to be outside of scientific description. Persons are needed for the anonymous objectives of science to disclose reality, but they do not exist for science as agencies of other non-scientific truths and individual lives. Science as a social process needs scientific workers but not persons as unique and unrepeatable events of disclosure of the universe. The same is true with respect to society which needs not persons but masses of individuals which are much easily adapted to the norms of materialistic thinking and behaviourist stereotypes based in the criteria of consumption of the results of technological progress. Modern atheism exploits this aspect of modern science by insisting on effective non-existence of personhood as a philosophical and theological notion. The oblivion of the person is treated by Christian theology as an encroachment on the absolute priority of the human world and those communal links in human societies which have formed the spirit of the Christian civilisation and integrity of its historical paths through communion with God. The oblivion of the person is the encroachment on 
the historical significance of its history impressed in the architectural image of European cities, masterpieces of art and literature, in the very way of European thinking and its values. The oblivion of the person constitutes an attack on all traditional forms of societies and life, which by the logic of the economical must cease to exist or become unobservable.

To defend the person and reinstate it to its central status in the dialogue between theology and science becomes a leading motive of the theological commitment. To reinstate the person means to understand that the problem of theology and science manifests the basic distinction and division of two attitudes to life in one and the same human person. The dialogue between theology and science becomes the explication of the split between intentionalities which the human spirit attempts to reconcile. This, using the language of Husserl, forms one of the infinite tasks of the human spirit to understand the meaning of existence. The very fact that this dialogue exists attests that human beings transcend the conditions of their physico-biological existence, the self-realisation of a special place in the universe in which the function of the Divine image in man is realised (Berdyaev 1944, p. 94). Thus the fact of the dialogue attests also that it contains the elements of transcendence and asymmetry between theology and science related to the human condition of personhood. It is this asymmetry, articulated in reflection, which we call the theological commitment, by confirming once again that this is an existential commitment. Correspondingly it seems doubtful that the dialogue between Christian theology and science is possible without faith that both theology and science represent modalities of the relationship between humanity and the Divine. Thus the dialogue ultimately contributes to growth of faith in God, to that infinite task which aims to restore the salvific Divine image in man.

\section{Theological commitment and reinstallation of personhood}

Science and technology make human life dependent on its own advance while having no power of foreseeing its outcomes. On the one hand a world dominated by technology tends to increase the sense of alternative futures which are available to humanity, on the other hand it tends to decrease our sense of control over this technological future and our ability to outline humanity's infinite tasks independently of technological necessities. It was claimed that technology is going out of control so that the vision of the future in a technological age is vague and often depicted grey and sorrowful. Eschatology is present in this uncertain future as a doomsday intuition. But this intuition reflects not so much the problems of the technology as such but rather the problems of moral self involved in advancing the appropriation of the world through technology. For some advocates of Christian ethics this observation was sufficient in order to reject technology for the sake of preservation of Christian values; the naivety of this rejection is obvious since technology permeates all layers of contemporary human society, including the Christians. ${ }^{12}$ The abandonment of technology is inconceivable and utopian. However, technology is capable of making its devoted adherents "transcendent-vision-blind"13 in the sense that it diminishes human ability to be attentive to those unusual experiences which cannot be presented in the phenomenality of objects and hence explained or imitated through scientific methods and technology. ${ }^{14}$ Paradoxically, technology as such represents a kind of transcendence of the originally natural things, but not artefacts. This is why it seems even more paradoxical that one type of a spiritual activity, that is transcendence from the natural, realised in technology, modifies human spiritual and corporeal life to such an extent that it stops not only genuine communion 
with original nature, but also stops another transcendence towards the non-worldly. ${ }^{15}$

However it is because of the dominance of the scientific in collective consciousness that the secularism affects societies in their entirety, including those ones which are considered as deeply traditional in a religious sense. The lack of the spiritually tantalizing identity of people leads to the fallacy of liberalism as a movement against everyone and everything which is traditional and historically persistent, capable potentially of undermining the cohesion of society, its stability and hence happiness and prosperity in a limited period of time.

It is not difficult to realize that beneath all these qualifications one can detect the allegation against atheism, namely its intrinsic inhumanity, that is an attack on humanity's essence defined in terms of personhood and the Divine image. Then one can see how the logic of this diminution of persons receives it further reifications in socio-cultural realities. Since the ideology of historical materialism imposes the demand for "globalisation" and hence "multiculturalism" as a disguised form of the international economic slavery, one naturally faces the question of the possibility of traditionally orientated ethnical and religious communities. Within the logic of the latter all such formations must become obsolete since they hinder economic growth. For those who critically approach this stance on the abolition of the many centuries traditions and styles of life the question remains: "Where is the place of tradition, religion, religious communities and ultimately of the Church in all this?" One can press further and ask about the place of a critical function of theological and ecclesial thinking and whether all of them are to be considered irrelevant.

According to this view all "religious traditions" fall under rubrics of collective identities and thus are fictional and prone to nationalism
(Llosa 2011, p. 117). However, what is forgotten here is the historical meaning of collective identity related to religiosity. A simple example is that the religious identity of the European Christian nations formed cultural monuments and civilizational delimiters of that which modern generations of the Europeans take for granted. It is also forgotten that the very technological advance and scientific appropriation of the world became possible because of the once initiated support of education and research in Western Europe by the Catholic Church. In addition, one must raise a purely philosophical argument that any supposed all-unity of people, as the unity of mankind remains no more than an eschatological ideal, not achievable in the present age (Goutner 2013). This implies that any aspiration to such an ideal presupposes a hidden tendency towards the faster end to the world. Thus the appeal to non-communal, non-cultural and non-religious identity remains as such an abstract idea devoid of any existential meaning. The case of the countries of the Orthodox civilisation resisting the postmodern social trends give a limited support to this conclusion.

Thus here is the fundamental question that Christians should ask themselves "Why is the Church and its theology as its experience?" Christians can respond to this only in one possible way: Church and its experience represent humanity's deepest need to attain immortality, that is to achieve the state of freedom from all necessities of this world (related to the conditions after the Fall). Immortality must not be understood in a physical and biological sense, for even physics makes it clear that the present state of the universe will not last forever and our physical survival is doomed. To attain immortality means to have an awareness of death as a part of the biological condition. This is not a trivial statement in the midst of the social reality which lives in the denial of death. One implies here not simply a physical 
death because of accidents, violence, terrorism, starvation and injustice. One speaks of death at the ontological, cosmic level, for example as scientific understanding that the existence of whole planet is contingently dependent on the interruption in death in the whole universe after the Fall. ${ }^{16}$ We are lucky of living in that cosmological era which supports biological life (anthropic principle). We are surrounded by the hostile stellar winds, threatening comets and asteroids, instabilities in the moon dynamics which is pivotal for the stability of the earth's axis of rotation, etc. We are contingent upon billions of years of not well understood evolution of the universe which can hardly to be made a home for man. We are freaks of the universe (Eric Fromm) living in the conditions of non-attunment to it (Jean Francois Lyotard) and inherent physical incommensurability with it. We are living in the universe which is "enframed" through scientific modelling and computational synthesis thus accelerating our "planetary (cosmic) homelessness" (Martin Heidegger). All this, being reflected upon theologically, tells us that we do not have too much time in order to fulfil our divine destiny.

Science teaches us of physical and biological laws which demonstrate how vulnerable we are in our physical and biological appearance. We can exist in a very narrow strip of physical conditions matching the biological ones. We are mortal in the physical universe, because we are ontologically finite. It is because of this biological and physical finitude that, we, being endowed with rationality (logos) and remaining in the universe, crave for immortality and commensurability with the infinite. But this infinite is not in the universe as we see and understand it. This infinity proceeds from us who were born into the conditions of finitude by the power of the invisible but infinite origin. We always struggle with the mystery of our birth, we always unfold the mystery of being in the perspective of understanding ourselves.
Human beings crave for immortality in the mortal universe because they have a gift of logos which relates them to aletheia, that is to truth. It is this Greek logos as truly existent which reveals to human beings not the uninterpreted necessity which governs the universe, but discloses the truth of existence of God in the mode of love, for love itself is the most supreme principle of creation, preceding and exceeding creation itself. Thus the need to attain immortality is the need to find the love of that Who can ultimately be called the Father of "all that was in all".

But science and technological culture, in spite of ingenious techniques of curing human bodies (that is to love them), teaches us how to destroy them with an incredible efficiency. By so doing it manifests not only our intelligent supremacy over nature, it demonstrates our intrinsic insignificance as natural creatures. Science teaches us about our temporary and contingent nature, it teaches us and warns us that we are nearly outdated. It is through this that science, in its apophatic stance on humanity, is doomed to direct our attention to immortality as a radical alternative to mortality based on the physical condition. It directs us to the biblical alternative "thou shall not kill" because we are nearly and already killed by the nature's response to our actions. In this sense the question of the dialogue between science and religion (theology) is fundamentally incomplete: rather one speaks of the radical transcending of everything which science asserts on our mortality and our uncritical attitude to death. The question is not of reconciling scientific culture with theology, but of using the latter in order to affirm with a stronger force that theology aims at something other, the otherness of transience and mortality, temporal decay and corruption of bodies and the world's order.

Taken in this historically contingent incarnation science and technology demonstrate us that the good creation of the good God, still 
being contingent and open to different attitudes, if is approached on the grounds of exploitation does not respond to humanity in that God-given fashion which it expects from us. The manifesting excess of death in the world can only be balanced by the Eucharistic action when the world as such is seen as a sacrament and an opportunity of transition to immortality. Here we come back to ecclesiology as reality of the Church, as that reality which attempts to fight mortality of bodies and souls by commemorating that ecclesial event in which the possibility of immortality as an ontological option was revealed to humanity. Correspondingly through this Eucharistic ethos the vision of the cosmic reality in the perspective of immortality can be transfigured.

Thus the Church and its theology is for those who understand that all ephemeral, intrinsically limited and damaged phenomenality of social reality based on "enframing" by science, political and religious ideologies, as well as by social dogmas, derange their longing for immortality, distort the sense of life and death, deny any meaning in questions about the world, deny existential uniqueness of persons and the value of beauty in communion with the universe. The Church and it theology is for that "yeast" of people ${ }^{17}$ who do not accept nihilism. The wisdom of the Church is for all those for whom the humanity of humans, the naturalness of nature, the justice of the polis, and the truth of knowledge remain absolute values.

\section{Theological Critique and Neo-Patristic Synthesis}

The wisdom of the Church demands a turn to what is called tradition. The tradition of the Church is often called Apostolic and Patristic. However what makes the historical position of those who lives in the $21^{\text {st }}$ century similar to that of the Fathers of the Church is that we live in the same historical reality, that is, after Christ, in which the Fathers lived and proclaimed their message about Christ. It is in this sense that our age can still be considered as the age of the Fathers and an appeal to the tradition as the guide line for modern theological development means effectively the appeal to a new Patristic synthesis, the synthesis of our own age ${ }^{18}$. Such a "Neo-Patristic Synthesis" was advocated by one of the leading Orthodox theologians in the $20^{\text {th }}$ century Fr. Georges Florovsky ${ }^{19}$ and aimed to rearticulate the fact that the Greek Patristic contribution is important for the catholicity of faith and existential implications not only in the Orthodox context, but also in Western Christianity. It is through this synthesis that it is vitally important to make the position of the historically united Orthodox Christianity heard and understood as contributing some novel ideas including not only a combat of modern atheism, secularism and nihilism, but also of provoking an apprehension of cosmology [and culture] by Christian thought not only at an academic level, but incorporating cosmology into existential contexts of contemporary humanity in order to face the consequences of the all-encompassing scientific and technological invasion in the very core of the human condition.

The realisation of this objective implies an invitation for contemporary theology to work with a view to a synthesis which, historically, had been already in existence during the early patristic period. Thus the Christian theological consummation of cosmology should follow a similar route, adjusting factual ecumenicity of science to the catholicity of Christian faith. The appropriation of cosmology by theology, or science's consommation as justification through theology, will have to follow the historical example of the early Church in the way it reacted to the Hellenistic philosophy and natural sciences and the views of the world of the time. It seems plausible to name such a strategy of appropriation 
of science as "a new patristic synthesis of theology and science". This new synthesis is envisaged as a mixture of premodern and postmodern exploration: its premodern character includes the invocation and recovery of a patristic ethos in which theology is inconceivable without its ascetic and mystical justification, as well as ecclesial communion; whereas its postmodern dimension, comprises all benefits of the latest philosophical development, including, first of all, its phenomenological advance. The sought synthesis as well as the objective of writing does not seek to discuss facts of the case as such (including theories as such facts) but rather to explore the relationship (communion) with the universe (though its study) as a mode of existence in the created universe. This implies not to follow the way of abstract and unfruitful comparative research between theology and science for the sake of some analogies and arbitrary schemes ${ }^{20}$, but to articulate the encounter with the variety of manifestations of the universe in human life as the ontological problem of incarnate existence inseparable from its source in God.

The appeal to the neopatristic strategy imported into the discourse of theology and science has justifications through historical parallels between the state of theology in the beginning of the $20^{\text {th }}$ century and that one which one can be indicated nowadays. According to G. Florovsky, Orthodox theology in the $20^{\text {th }}$ century experienced an existential crisis consisting in the separation of abstract theologising from liturgy, and the loss of the sense of tradition, in particular its adherence to Greek Patristics, understood as post-Christian Hellenism. In other words, the Church's consciousness was lost in academic theologising which stopped theology from thinking of the split between Eastern and Western Christianity, the antinomy of monasticism and secularity in the Church's existence (which indirectly contributed to the disintegration of the human spirit into religious and scientific (metaphysical) modes (that is dualism of faith and knowledge)), and addressing any issues related to society, politics, culture and science. Definitely theology captured by the nets of metaphysical and transcendental styles of thinking, devoid of links with ecclesial experience of God could not adequately grasp the trends of modern thought about the universe without its own renewal.

On a purely theological side, Florovsky argued that Christian theology (both in the East and in the West) needs renewal through restoration of its spiritually disintegrated mind in the unity of the tradition which is apostolic and patristic. The diversity of theological schools and ideas should acquire their intrinsic catholic context and the mind of the Fathers of the united Church. It is in this sense that theology should be referred to the experience of the Church, to its ever-living tradition and its liturgy. Any academic theology without these grounds in the living experience of God loses sense and its role in ontological transfiguration of humanity. ${ }^{21}$ Theology must return to its immediate historical and existential context, to human beings who are often forgotten in the course of abstract theologising.

There are two crucial elements in Florovsky's thinking: the first is the immanent presence of the Holy Spirit in history after Pentecost (Florovsky 1972[2], pp. 37, 45, 47), and the second is the constant presence of Christ in history. Florovsky advocated the fusion of world history (sacred because of the participation of Christ in it and his ongoing presence) and Church history. He persuasively expressed this idea: "History of the Church is the mysterious process of the formation of redeemed humanity, which will be consummated and recapitulated and not simply judged and abrogated in the last days....There is an accumulation of permanent Christian values in the history of the Church, in the process of existential assessment of the divine truth and 
life" (Florovsky 1961, p. 205). This explains to some extent why Florovsky put so much stress on the old and new patristic synthesis not as an intellectual achievement of humanity but rather as its ecclesial achievement when Hellenistic philosophy, as an already existent manifestation of the human spirit, was involved into Christian ecclesial history through the Incarnation and Pentecost. It is in this latter sense that one can assert that the human spirit present in preChristian Hellenistic philosophy was acted upon by the Holy Spirit thus creating a unique patristic synthesis. One can then conjecture that in similarity to what happened in old patristic times the appeal to a neo-patristic synthesis in the $20^{\text {th }}$ century (as well as by us in the $21^{\text {st }}$ century) can not be treated as mere historically contingent fact, but rather has features of a new break of the Holy Spirit into history in order to reaffirm Christianity in the modern world. Hence a neo-patristic synthesis reveals itself as a carrier of a "teleological idea" faithful to that of the Christianised Greek Hellenism of the past, in which the teleology of universal history of salvation, as authentic history and destiny of humanity, was articulated and understood by the Fathers of the Church.

A neo-patristic synthesis aims to unveil the most precious questions of the modern human condition in a theological frame of mind, which is not only anthropological but also ecclesiological. ${ }^{22}$ Thus our attempt to involve science, as a cultural phenomenon, into the dialogue with theology along the lines of this Neo-Patristic existential trend is intrinsically ecclesiological. The impact of theology on the ever-evolving human condition can only be achieved "when theology shall return to the depths of the Church and lighten them from within, when reason shall find its centre in the heart, and when the heart shall mature through rational meditation" (Florovsky 1975[1], p. 191). In the same way as the reason, devoid of the light of the spiritual intellect and of the heart, cannot attain the clarity of truth in its own tendencies and its own historicity, the heart itself, devoid of the rational reflection upon its own movements and experiences, cannot make itself manifest to the public life of the Church; for what it (heart) lacks is exactly that which was called "theology" in a Patristic age, that is theology as demonstrated faith.

For Florovsky the lack of this maturation of the theological heart through rational meditation was associated with the abandonment of Patristic tradition and it is here that one can see the origin of his thesis that the goal of theology must be linked to acquiring back the style and methods of the Fathers. However the acquisition of what Florovsky calls "Patristic mind" is not a sheer acquaintance with ancient texts and extraction of relevant quotations for modern arguments, it is rather the possession of the theology of the Fathers from within (Florovsky 1975[1], p. 191). The acquisition of "Patristic mind" is thus the developing of a faculty of intuition which is capable of recognising in the Fathers the true witness and ever-present testimony of the Church, which survived all cataclysms of the Church history, as well as history in general ${ }^{23}$, that is to recognise the underlying Reason (logos) in the development of the Church consciousness, the Reason which forms its telos. This means that the return to the past in terms of the Fathers' heritage does not imply the repetition of their sayings as borrowings from the past, but rather the restoration of the spirit of the Fathers as guiding us to the future in scientific research as well as culture. The reintegration of our mind with the spirit of the Fathers implies also the restoration of our catholicity with the Fathers as that universal communion which can effectively validate the claim for the authority and truth, attained in the living tradition, in the midst of the contemporary postmodern cultural environment. However, 
the return to the Fathers must be creative. This implies that "one has to reassess both the problems and the answers of the Fathers" with an element of self-criticism. "We must not only retain the experience of the Fathers, but moreover develop it while discovering it, and use it in order to create a living work" (Florovsky 1975[1], p. 200), and this, according to Florovsky "brings us to the concept of a Neopatristic synthesis, as the task and aim of Orthodox theology today" (Florovsky1975[2], p. 22).

It is evident that the ethos of a neo-patristic synthesis is to involve theological thinking into a historical process understood not as a contingent flux of events and happenings in human society, but as the theanthropic process which is determined by Biblical events whose telos is the union with God. This means that all particular modalities of the Church life and its theology, in spite of the fact that they can appear (to some non-ecclesial consciousness) as historically contingent and archaic, in their depth, have a meaning of being sanctified by the action of the Spirit of God upon different stages of human history. The manifestation of this sanctification, its historical incarnation, is the Church's worship, its eucharistic ontology as making the Church existent and alive. In patristic times theology was inconceivable without worship and it is as worshippers that the Orthodox always stayed in the tradition of the Fathers; this is the reason why "they must stand in the same tradition also as "theologians". In no other way can the integrity of Orthodox existence be retained and secured" (Florovsky 1975[2], p. 22). It follows that this is also the reason why a neo-patristic synthesis must be considered as the task and aim of Orthodox theology not only with respect to its own development but also with respect to its interaction with the world of contemporary culture, its philosophical and scientific thought.
All those who studied and developed old patristic ideas can be considered as the Fathers of the Church, for they contributed towards that patristic heritage which has a mode of perpetual existence, as has the Church itself. That is why those modern theologians of the Orthodox Church who created their own individual and unique experiential way of communicating with God, must be studied and understood in order to continue the never-ending line of ecclesial fullness and tradition. It is in this sense that the tradition affirms itself as a never-ending and "living tradition" 24 and that the age of the Fathers has not finished in the past. Those ascetics of the Orthodox Church who always lived with the mind of the Fathers through worship and liturgy give us a contemporary "practical" example of their own Patristic synthesis, which should be studied in order to retune one's mind for communion with the Fathers.

For Florovsky the acquisition of the "patristic mind" meant to see theology in the context of living faith which supplies all theological intellectual expositions by the immediate experience of God, without which any theology transforms into an "empty dialectics, a vain polylogia, without any spiritual consequence" (Florovsky 1972[3]), p. 108). Florovsky argued for the integrity of theological thinking which included not so much citations and reading of the Scriptures and the Fathers, but, in fact, a prayerful communion with the Fathers as persons with their experience of God and life. This communion through the centuries can only be achieved within the integrity of the worshipping and eucharistic experience of the Church as a factor of its perpetuality and existence: "..it can be contended [that] the "age of the Fathers" still continues alive in the "Worshipping Church". Should we not recover "the mind of the Fathers" also in our theological thinking and confession? "Recover", indeed not as an archaic pose and 
habit, and not just as a venerable relic, but as an existential attitude, as a spiritual orientation" (Florovsky 1975[2] , p. 21). However the recovery of a spiritual orientation in a style and manner of the Fathers means, in fact, a change of the spirit of modern theologising from passive study and simple learning to a constant invocation of that Spirit who guided the Fathers and who allows us to enter communion with them. It is through this communion that contemporary theologising can acquire a reliable and novel path towards its future through its reference to the tradition, which is not a relic and dead sediment of the outgoing past, but, on the contrary, a spiritual anticipation of the past as the constant presence of the Spirit. Then all different aspects of human living activity will become seen through the constant presence of Christ in history which drives humanity to its eschatological destiny, and knowledge of which is being inaugurated by the Spirit in every liturgical invocation which is ever performed by the Church.

\section{The Existential Reintegration of Humanity as the Central Theme for a Neo-Patristic Synthesis}

Patristic theology is relevant and appropriate in the contemporary world because it has an essentially existential character. Florovsky asserts that "the Fathers were wrestling with existential problems, with those revelations of the eternal issues which were described and recorded in Holy Scripture. [It] would make a suggestion that St. Athanasius and St. Augustine are much more up to date that many of our theological contemporaries" (Florovsky 1972[1], p. 16), and this is the reason why "what we need in Christendom 'in times such as this' is precisely a sound and existential theology" (Florovsky 1972[1], p. 15). Florovsky means here existential theology as opposed and entirely different to "strange ideologies" which form pseudo-theologies of a "modern" age. However the existential nature of theology for which Florovsky appeals in the context of a neo-patristic synthesis does not mean dealing with issues of life and death in an ordinary mundane sense but it asserts theology as a mode of being which itself is preoccupied with personal existence, existence and fullness of life as an event of communion with the Other. To be a contemporary theologian of a "patristic kind" means to live in faith, following God's will ${ }^{25}$ (with respect to this, a particular theologian is a unique and irreducible event of existence), and carrying out the task of a neopatristic synthesis as proclamation of truth about the Word of God (Florovsky 1972[3], p. 108). Theology must become dialogical (not so much expounding some general things about God and the world) in order to talk about God in dialogue with living human beings, the dialogue which is inherently in God and with God. Thus theology as thought can never be detached from an existential action. J. Meyendorf refers to Greek Fathers in order to draw a parallel between the situation which Christianity faced in the first centuries of the first millennium and the task which Christian theology faces in our contemporary society: "the Church needs theology to solve today's problems, not to repeat ancient solutions to ancient problems. The Cappadocian Fathers are great theologians because they succeeded in preserving the content of the Christian Gospel when it faced the challenge of the Hellenistic philosophical world view. Without their partial acceptance and partial rejection of this world view, but first of all without their understanding of it, their theology would be meaningless (Meyendorff 1978, p. 168).

Seen along these lines, a neo-patristic synthesis should thus imply the understanding of the contemporary stream of thought, be it philosophy or science, from the perspective of communion events. Orthodoxy exists in the world which is dominated by scientific ideas 
and technological applications and where human reason is tempted to believe in its sovereignty and power to control all aspects of being. It is in this sense that modern science and culture challenge theology and religion in general, and Orthodoxy in particular. It challenges the religious mind, that is it attempts to split the integrity of human persons to whom the reality of things is given in existential events where there is no separation between communion and being. Then the defence of the Christian stance on the meaning and value of human life, as well as their further articulation in face of technical progress, should assume that that rationality, which underlies the intellectual development of humankind and its technological overtaking of the world, must be contemplated as relevant and valuable only from within the very fact of existence of persons for whom their being is existentially inseparable from communion. As a result, some aspects of scientific and technological progress will have to be rejected, some others will have to be accepted. Scientific and philosophical ideas cannot just simply enter a fruitless dialectical dispute with theology; rather they should be involved and sanctified into the "logic" of existential events as well as ecclesial realities which articulate and disclose the meaning of these events.

As we mentioned above, in all modern forms of the dialogue between theology and science, as it exists in the West, the prevailing approach is based on the so called natural attitude of the human mind within which both theology and science are positioned as outward activities of human subjectivity, whereas the activity of the very human subjectivity is taken for granted and is not subjected to any introspection and analysis. It was easy in this approach to reveal the differences between theology and science as they are given to humanity in its historical incarnation. However, an attentive mind can immediately enquire whether those differences have a deep existential character and whether they lead to any tension between theology and science if both of them flourish from the same centre: incarnate human subjectivity. It is by referring theology and science to immediate existential events that one can try to find the common root for both theology and science. But it can be anticipated in this case that the natural attitude dominating in the dialogue between theology and science must be suspended so that the dialogue becomes a problem of the split of intentionalities in one and the same subjectivity. But this should be done, not in order to correct theology, or construct some pseudo-theological systems, but rather for a different purpose, namely, to demonstrate that Orthodox theological anthropology will necessarily have to study man in conditions such as he is. This is the reason why theology is interested in that knowledge about man, which is accumulated by contemporary science. First of all theology is interested in the dialogue with those anthropological concepts which have been developed by philosophers in the last century; this is because in contradistinction from special sciences such as biology, psychology, sociology and linguistics, philosophical anthropology aspires to reveal some essential characteristics of man, to understand his nature and special place in the system of the world.

However, a neo-patristic synthesis must not follow the logic of a vague unified synthesis of Christian life and thinking with some modern philosophical and scientific ideas. This kind of synthesis would result in another intellectual monstrosity with no existential consequences. What is important is that all philosophical and anthropological stances in modern philosophy will have to be met with a grain of discernment. The quest for the meaning of human existence and the essence of the human condition in the universe, as asserted in science and philosophy, must be taken into account only to the limited 
telling Orthodox theology exactly what the meaning of personal life and what the sense of the hypostatic human condition are not. ${ }^{26}$ It does not mean that Orthodox theology judges or rejects any achievements of modern philosophy and anthropology; on the contrary, it takes all of them as its own problems which have to be known and mediated (not accommodated) in order to find a new way forward. However this keeps Orthodox theology away from a naïve hope of finding an all-encompassing synthesis in one particular historical period: this synthesis can only be thought as an eschatological task. It is only in this, very specific, sense that one can hope that the sciences whose meaning being elucidated and judged by theology, will have to "acquire" existential features, that is, to be seen not as abstract ideas and exotic theories about the outer world, but as those human activities which are intrinsically linked to the existential anxieties and spiritual aspirations of humanity.

Theology with all its faithfulness to the living tradition of the Church has to evolve in order to become existential not only in abstract philosophical terms as being imbued with anthropological issues, but existential in the sense that its fundamentals, that is the Church's definitions and dogmas, become a true guidance for people living in the contemporary culture. ${ }^{27}$ No genuine meaning of human existence as life in history and culture can be found outside religious anthropology with its experience of the ineffable mystery of that who can say "I am Who I am". In the same way as the supreme existential mystery of the Sinaite revelation cannot be objectified and understood apart from participation in the speech of God, existence in the created world (that is, the existence of the universe as well as human beings in it) can only be understood through an ontological modality of humanity which can be expressed as existence- participation and which is impossible to define discursively for it carries in itself some objective uncertainty. In all attempts to grasp the mystery of the facticity of existence of human persons, the actualisation of the very event when a human person is conceived in the midst of physical and biological nature can only be interpreted through the reference to the Bible, which speaks about the creation of man not as a result of an impersonal interplay of chance and necessity in nature but as an act of personal loving relationship with God, which places all sorts of questioning about existence in general (why there is something than nothing?) in the realm of constitution of the created in experience of communion with God. ${ }^{28}$

Humanity is defined through the universal participation of its finite representatives in the divine infinite: this is exemplified by Christ and as a commitment is embodied in particular social practices and cultural activities. The stance on participation brings not only a new vision of anthropology, but also new ontology (with all sorts of reservation which accompany the usage of this term). The latter can be characterised as relational ontology (in the sense which is used in a Trinitarian context when it is not situated between two or three poles but rather remains at both or three at once), as well as an ontology of a gift, that is not as not self-subsistent existence; this ontology is relational upon the transcendent source and as such, that is in its concreteness, is a gift. The entrance of the gift in the ecclesial ontology of Christian being naturally bring an Eucharistic response to this gift thus placing an abstract philosophising on ontology in a concrete ecclesial framework. Speaking differently, the claimed universality of Christian existence reveals itself in specific and concrete events of the Church life. Theology with its attitude to the world receives its proper place in the Church for which theology is her voice. Science, culture and politics as a mode of human activity and thus, by definition being involved in speech of the world 
together with theology, will have to become a different way of expressing the Sinaite revelation "I am Who I am" (Exod. 3.14). Being in a mode of relationality and gifted with existence, Christians contemplate being as being of Someone, for if there is no personal origin, there is no being at all. This implies that the universe of beings, as opposed to non-being, exists only in that one, who can affirm about his being through the universal voice "I am Who I am". The challenge for theology to mediate with culture and science is to convince the latter to contemplate the universe as inherent in the person of God, so that cultural dynamics and cosmological anxieties are to loose their meaning as outward and impersonal objectifications, and to express in themselves the presence of the image of the Person of God in the world revealed to the created humanity. But this requires that human beings will treat themselves not as impersonal physico-biological creatures whose life is driven by dispassionate laws of nature and who are doomed to decay and die, but as those agencies in the universe who possess in their inner essence the image of the Personal God, the image of Christ and the life-giving energy of the Holy Spirit and who through their communion with God establish harmony and the sense of life. The interfertilisation of theological realism and scientific or cultural realism aims to bring to light the intensity of a particular instance of existence through the events of communion with the Personal God who reveals himself by the light of a knowledge which is not a meaning or concept, but a name and a person, Jesus Christ. By participating in dialogue with the hypostasis of Christ one begins to comprehend the matter of the world not as alien landscape of the contingent natural forces and empty spaces but as the realization of the command of God "Let there be light". It is through this light of Christ present in the world and sustaining our existence, as well as in the light of knowledge, that culture and science as manifesting an exemplary human existence become possible at all. Thus understood, culture and science can be reinstated to its proper status in communion with God. This opens a way to a mediation between culture, science and theology in a uniquely different way which can be summarised through saying that all components of such a mediation constitute themselves through appropriation of each other. The challenge then is to be aware of the fundamental limits imposed on our effort to engage culture and science into interaction with theological realism if the whole enterprise is expected to be accessible to the wider academic and ecclesial communities and communicated in such words and writings which will enable a media for general discussion. The limits are, of course, our limiting abilities to imagine and speak about God on the grounds of discursive reason and rational thinking in general.

Here one means that any philosophically advanced means of delivering theology in terms unrelated to historical facticity and eventuality of revelation will fall into the trap of the Enlightenment's claim for the universality of the public reason and its ability to judge about events related to the Christian tradition. This "pure" Christian reason would obviously risk loosing any affiliation with an ecclesial setting of Christianity which makes it distinctively different from other religious traditions. Correspondingly, to preserve the true spirit and uniqueness of the Christian revelation and tradition in the background of the global space and time of the universe, as well as inside human history, this allegedly "pure" Christian reason itself must be criticised (in analogy with the Kantian critique of reason), placed in the framework of humanity endowed not only with the transcendental faculties, but with the Christ-centred personhood. In this sense the uniqueness of any particular saint or a Patristic writer is exactly in that the most general 
Logos (Wisdom) becomes manifest through and by the Spirit in a concrete and particular. This, however, does not imply that the cosmic, as well as cultural and social aspects of the human hypostatic existence are neglected and replaced in favour of the historically contingent and inter-personal. The issue is that the elucidation between universal and particular can receive its existential resolution only through ecclesial experience, where the concrete universality of the Eucharist makes it possible to resolve the perennial dichotomy between the illusionary and transient physical existence on the one hand, and the intentional, Divine-given infinitude, on the other hand. The overcoming of secularisation in appropriation of culture and science can thus be achieved if the transcendent-blind attitude to reality is subjected to the transforming metanoia originating in ecclesial events. It is here that the Christian stance on the nature of reality and its particular realisation in the neopatristic synthesis can have a fundamental effect on human anthropology, which being cascaded towards society, politics, technology and culture could form a definite alternative modern version of historical materialism. In this sense the NeoPatristic Synthesis in theology, endeavoured by Florovsky and Orthodox followers (as well as Catholic and Protestant theologians) in the middle of the $20^{\text {th }}$ century as an attempt to neutralise the destructive scientific atheism and secularism, can be considered as a historical attempt to fight the de-Christianisation of Europe and the whole world and which is worth of being advanced nowadays. The objective of such a move would be not to promote a kind of new-born religious fundamentalism, but a mediating and critical approach to reality of the human world in its totality which would allow humanity to conceive the sense of its own existence in the background of the created universe. By so doing, Christian stance through the neo-Patristic synthesis would contribute to the mediation between theology and scientific ideology acquired and exploited by contemporary adherents of atheism.

\section{A Neo-Patristic perspective on knowledge}

The validity and justification for implementing the idea of Neo-Patristic Synthesis in the modern world can come only if the objective of theology re-engages with and transfigures the world in all its aspects, including not only the world of passive nature, but the world of human society, its scientifico-technological, cultural and political dimensions. For this purpose Christianity possesses that One, after whom its followers call themselves Christians. In other words, the Christian attitude to the world and its possible theological transformation has it ground in the incarnate Logos, Jesus Christ. Since Christ remains an ultimate archetype of all possible ways of implementing engagement and transfiguration, the transformation of all implies the transformation in man in a way opposite, but mutually consistent, with the Incarnation, namely human deification as the way of seeing and acting in the world as much closer to that one of Christ: "As much as God is humanised to man through love for mankind, so much is man able to deify himself to God through love". ${ }^{29}$ The deification implies that man as microcosmos is capable not only of articulating the whole universe, but making it more and more humanised, that is makroanthropos..$^{30}$ In this sense theology makes cosmology and anthropology intertwined. This idea can be traced in the Church Fathers, in particular in Nemesius of Emesa and Maximus the Confessor. Not only the basic difference between sensible and intelligible in creation is reflected in man, but all divisions in the cosmos are to be mediated by man in order to restore the prelapserian archetypical unity of "all in all" in God. Practically this means to perceive 
and apprehend the created universe in its variety by referring it to the center and the source if its enhypostasisation, that is the Logos-Christ. The universe as physical creation will keep its difference from God, but its vision and sense become more transparent and soteriologically significant as if it would take place through the eyes of the Logos Himself. The accomplishment of this process requires metanoia (change of mind) and purification of the heart. This process relies on the preservation of the $\log$ s $^{31}$ of humanity through changing its tropos ${ }^{32}$, as a mode of existence. The natural assumption in Maximus the Confessor's time was that the logos of human nature, relying on the physical and biological stuff of the created universe, cannot be subjected to such a drastic change that the hypostatic union of body and soul will not stand. Thus Maximus assumed that the way of deification excludes any misuse of creation, such that the logos of the human nature could be threatened at all. In this sense, according to patristic writers, even the process of creative transformation of the world does not imply, that through the changing of the tropos of humanity, this very humanity can change the logos of human nature simply by destroying incarnate humanity as such, for example through the technical implementation of scientific "progress". ${ }^{33}$ Thus the patristic vision of the destiny of humanity remains limited, simply because its era and milieu did not foresee the accelerating and drastic domination of science in human life after the $17^{\text {th }}$ century. For example, Maximus the Confessor, as a thinker of the $7^{\text {th }}$ century, while not being engaged with the world outside the Church, did not contribute to the theory of culture and its scientific mode. Correspondingly, if one attempts further a theological appropriation of the modern world along neo-Patristic lines one needs to place theology in the context of the modern discourse on society, politics, culture and science. Thus the Neo-Patristic Synthesis' orientation becomes radical in that participation in the Church mysteries is considered as making it possible for theological knowledge to mediate all other forms of knowledge placed in human culture and dependent on social and political factors. In this sense the neo-Patristic synthesis is a tendency for transcendence beyond the boundaries of knowledge, that is it is theological per se. It destined to become a radical form of mediation between of all forms of knowledge bringing to a new light the fact that any knowledge is a gift. This mediation implies that modern theology needs to learn from the ways in which this gift of knowledge has not always been embodied in the life of the Church and in Christian tradition. Thus, while the Neo-Patristic Synthesis appeals to the Church and its roots, its patterns of thought and the whole ethos does not exclude treating these roots as bearing witness to all of humanity. The pattern of relationship between humanity and God which is displayed in the Church as a gift and possibility, is open to humanity at large, in particular in that which is concerned with their understanding of its own place in creation in view of new knowledge. However this understanding is not to assimilate and dissolve the essence of a theological gift-oriented vision of the world thus keeping theology within its unshakable pillars of faith, ecclesial tradition and communion. The very possibility of knowledge as a gift is manifested through the Divine image in man following from Christ, as a centre of the gift of Christian theology. Thus theology must be capable of understanding modern ways of living and thinking and, at the same time, of being a criticising modality of $\operatorname{life}^{34}$, remembering that all modes of the human activity represent a radical gift of existence, of life whose ontological priority proceeds from God. In this case in all compartmental and educated apprehensions of reality, including nature, society and humanity, science itself receives its justification and understanding in terms of the 
radical gift of the dynamic theo-logia, that is of the pre-predicative sense of existence in God and through God. The challenge of the theological commitment along the lines of the Neo-Patristic Synthesis is to bring a new light to this intrinsic conviction of the Fathers of the Church.

The Fathers of the Church were engaged with society at large and its trends of culture and science only to the extent they had to defend faith within their surrounding culture and make it demonstrable. In this they did not advance their understanding and foreseeing of the historical development of culture and science. Thus their relevance to contemporary problems posed by postmodernity and modern atheistic and secular trends is limited. However even in the conditions of such a limitation the main line of the Fathers' thinking remains never irrelevant and outdated, namely that knowledge as an indispensible mode of culture (and of the microcosmic transformation of the world into makroanthropos) is the Divine gift, so that any attempt to detach this knowledge from its inner source in the life of man (as a central primitive world - this is an implicitly phenomenological stance) deprives this knowledge of any existential and soteriological sense. Here arises a radical approach to the very possibility of knowledge of the world, including humanity and society, as originating in God. This stance is not an extreme fideistic position per se, but rather the reenactment of the stance on knowledge and education in premodern times. Indeed one can provide the reader with a couple of examples related to patristic times. The Fathers of the Church always appreciated the special nature of knowledge (in modern parlance the "sciences") and its limited ability to talk about the nature of things. For example, according to Gregory of Nazianzus (Theologian): "Granted you have a grasp of revolutions orbits, ... and all other subjects you take such inordinate pride in knowing, this is not a real grasp of the actual things by any means. No, observation of a certain movement is confirmed by further exercise and unifies the observations made by many others. It then thinks out a rule and gets the title 'knowledge'.....But if you are very knowledgeable of these subjects and are on the look-out for proper respect, explain the cause of the order and movement." ${ }^{\prime 35}$

The surface appearances as such, even if they are combined in groups and law-like patterns, do not shed the light on the ultimate sense of things, their logoi, that is the contingent facticity of thing, their ordering and movements. As was expressed by Olivier Clément: "Every created thing has its own point of contact with the divine energy, the virginal point, logos, sophianité in which this thing is based and, at the same time, through which it is magnetized towards its fullness. Without logos, name there would be in created being only a shocking absurdity of the deaf and dumb masses in the abyss of darkness" (Clément 1976, p. 86). Since knowledge of any thing implies the hearing and communing with the effective word, every tiny thing is to manifest the Triune Creator, in which the Logos is inseparable from Pneuma. The very being of things links to the source of their existence in the Father. Their intelligibility, of a logical order, links them to the Logos, and their life as motion points toward the presence of the Holy Spirit, the giver of Life, that grants them ground and fills them.

Longbefore Maximus, ClementofAlexandria attempted to formalise a similar conviction of the grounded nature of knowledge in the Divine by using philosophical tools. Speaking of knowledge Clement related it to the enquiry into the nature of truth as something which is all-embracing, including all particular truths. Truth is one, and it is God's truth. That is why, according to Clement, philosophy or the sciences are characterized by investigation into truth and the nature of things. ${ }^{36}$ But this is not a divine truth (Strom. I:6.); rather, it is a partial truth. Philosophy can contribute 
to the comprehension of truth, "not as being the cause of comprehension, but a cause along with other things, and co-operator; perhaps also a joint cause" (Strom. I:20). Similarly there is only partial truth in the sciences: "In geometry there is the truth of geometry; in music, that of music; and in right philosophy, there will be Hellenic truth" (Ibid.). Clement claims that the Greeks, through the gift of reasoning granted to them by God, approached this truth but did not manage to collect together the divided truth and to find its source in the Logos of God: (Strom. I: 13). Philosophical knowledge as such is incomplete, for 'it cannot by itself produce the right effect' (Ibid.). Clement contrasts it with the Christian teaching, 'which, according to the Saviour, is complete in itself and without defect, being "the power and wisdom of God" ' (Ibid.).

The Greek philosophers, according to Clement, participated in the truth that comes from the Logos, but they did not see this truth because they did not have faith in the Logos of God and thus could not have access to the only true demonstration which is supplied on the basis of the Scriptures. This is why a demonstration based on opinion cannot be qualified as divine, but only as human, i.e. as mere rhetoric, whereas a demonstration that is based on reasoned knowledge produces faith in those who wish to learn of God through examination of the Scriptures. This faith that is supported by philosophical methods is called by Clement a considered faith, i.e. a gnosis, and, according to Clement, forms the subject matter of theology. Clement has formulated a methodological principle that allows one to treat sciences and philosophy as two different ways of knowing which cooperate in truth. Whatever science and philosophy offer to theology it can easily be incorporated by the latter for the purpose of deepening and extending faith within the boundaries of the Church's definitions. ${ }^{37}$
The Fathers of the Church, having faith in God and understanding that the appearances of things never grant access to ultimate truth, used the Divine gift of discernment and contemplation of the natural things in order to look beyond empirical appearances for indications of the Divine presence in nature, and they never allowed their thought to degenerate into pantheism. They firmly maintained the fundamental Christian gift, that is faith that the transcendent God of the Scriptures created the world ex nihilo, and that $\mathrm{He}$ is present in the world through the divine logoi of all created things. ${ }^{38}$ Thus the Fathers considered their primary task as to interpret scientific knowledge theologically, thereby criticising, delimiting and at the same time pointing to its ultimate source in the Divine gift to humanity to articulate and summate the universe.

In order to see truth behind the empirical appearances the Fathers employed contemplation (theoria) of the the logoi of created things (as their immutable and eternal principles).$^{39}$ Maximus the Confessor considered the contemplation of the logoi of created things as a mode of communion with the Logos leading ultimately to mystical union with God. The fundamental aspect of this communion is that it must be exercised through the purified intellect (nous), so that the contemplation of the logoi is not the same as either empirical perception or mental comprehension. It is a mode of spiritual vision of reality, where the ontological roots of things and beings are seen as having their grounds in their trans-worldly otherness. Is such a contemplation relevant for knowledge achieved through modern scientific research? Indeed, scientific research usually starts from things which constitute our sense of ordinary reality, though sometimes mediated by experimental apparatus. However, there is another aspect of scientific investigation which involves the shaping of contingent empirical findings into a theory. This requires access to 
symbolic language, mathematics for example, which makes it possible to talk about intelligible entities standing "behind" the outcomes of our measurements (this takes place when physics talks of elementary particles, fields, global geometry, the totality of the universe, etc). It is understood at present that this way of looking at reality corresponds to what is called rationality. The source of this rationality is hidden in the divine gift of representing the universe as it was seen by the Logos-Christ. It is only because of the existence of this divine dimension in human beings that it is possible to infer from nature to the presence of the divine intentions behind created things. ${ }^{40}$

According to Maximus, the Divine Logos is present in all things, holding their logoi together. Thus the world is filled with the divine reality, and man, in accordance with his logos, can have knowledge of the logoi of things: "Indeed, the scientific research of what is really true will have its forces weakened and its procedure embarrassed, if the mind cannot comprehend how God is in the logos of every special thing and likewise in all the logoi according to which all things exist." ${ }^{41}$ Man knows things from nature, in their differentiated mode, and creation is seen as (morally) divided into parts. Whereas the natural contemplation of things means the knowledge of the principles of existence of things in their differentiation, the mediation between moral divisions in creation is to bring all sensible creation through the unity of the logoi of sensible things in one Divine Logos which constitutes the principle of creation. In order to achieve this contemplation man must have a gift of being detached from sensible creation to see things spiritually. This kind of contemplation of natural things is compared by Maximus with the angelic knowledge of sensible things, for angels know the logoi of sensible things directly, as it were, 'from above'. Because the Incarnation, according to Maximus, takes place in the words of the Scripture, but also in the logoi of things that are held together in the universal Logos, spiritual ascent through the contemplation of the logoi of creation is destined to lead to the Logos-Christ. The knowledge of things of the world thus acquires all the features of participation in the divine: "On the account of the presence of the Logos in all things, holding their logoi together, the world is pregnant with divine reality, and knowledge of it - through the rational quality of man, his own logos - is itself a kind of communion with God, a participation in divine things through the aims and purposes that are recognized in creation" (Thunberg 1985, p. 127). The natural contemplation of the different logoi in the one Logos thus manifests the exodus of man from this world to God, as the truth of the whole of creation is revealed by and in the Logos of God Himself. Maximus treats all of this mystagogically, that is as a liturgical process on a cosmic scale: the "cosmic liturgy."

Saying all this, it was characteristic of Maximus and of the Greek Fathers in general that they could transcend spiritually the material world in order to contemplate its logoi, and through this contemplation praise the Creator of the natural world. Afterwards they could come back to nature and see it in a new light, from the perspective of its ends and purposes, from the perspective of the Christ the Logos. For the Fathers that which we call nowadays nature was empty before Christ. Its true meaning was opened to us only through the mystery of the Incarnation. But the Fathers, though worshipping the uncreated through nature, were always aware of the danger of pantheism, for the passage between material and spiritual (as the easiest mental image of the uncreated) was made with such an ease that the fundamental distinction between them could be confused. The Fathers never worshipped nature, but only its Creator. This is why when we speak of the 'cosmic liturgy' of Maximus as a form of 
mediation between heaven and earth, visible and invisible we must remember that the overcoming of the divisions in the creation on the moral level does not imply the elimination of ontological differences. Praying to the Creator does not remove the distinction between Him and the creation. God and nature are not identical, but one may seek access to nature in order to find God, and, vice versa it is through faith in God that nature can be disclosed in its true names at all.

By interpreting knowledge and nature theologically, through faith in God, the Fathers of the Church did not advance understanding and foreseeing of the historical development of culture and science (in fact, this was not their task as defenders and promoters of Christian faith). This is the reason why any advocacy for the relevance of Neo-Patristic Synthesis in our age must extend its scope much further than the old Patristic Synthesis in what concerns a theological judgement of human cultural and scientific activity related to the present age. But this in turn requires one to deal not only with epistemological questions, such as the dialogue between theology and science, but with action as long as science is considered to be a practice affecting the human condition and changing the world in accordance with the soteriological tasks. The task of humanity is to bring (through action) nature, society and humanity (as empirical reality) to their highest level, to transfigure them in such a way that their logical and sophianic essence could receive full realisation. One speaks here of the realisation and establishment of that principle of the Divine presence in the world which unifies different parts of the human activity, such as politics, economics, science and culture. The detection of such a principle could be done through human creativity and many-faceted reality of the world (disclosed through the sciences) even if the latter do not have any direct relation to the aspects of life of Christian Church. Then one can talk about new comprehension of Christianity, its new revelation which does not change Christianity, but brings it to a new comprehension (C.f. Bulgakov 1999 , p. 282). However human creativity must not be absolutized, not only because human beings cannot produce anything new in the sense of creation (and thus they are doomed to deal with recreation and replication of something which is already given (C.f. Bulgakov 2002, p. 321)), Christian theology must appropriate this creativity creatively, that is critically. ${ }^{43}$ This means that all human creativity as being embedded in the fabric of the created can have a theological sense and justification if it serves to the goal of bringing man and the universe closer to God, that is to make creation humanised. If this pregiven soteriological objective is ignored, all human activity could finish with producing a demonic and non-human world, dimmed of truth and the divine light. The last point is of utmost importance because humanity, in order to preserve its archetype of the divine and human, Christ, must preserve the logos of its own nature in all creative acts by changing and renewing only the tropos of its nature. However this exactly represents a serious problem in the present state of humanity, which by "experimenting" with nature through scientifico-technological (as well as indirectly social and political) changes of it tropos of existence, risks not only not to preserve the logos of its own nature, but, in fact to annihilate its incarnate presence at all. The danger here is that this gross imbalance in preserving human nature (which effectively removes the archetypical image of the incarnate Christ) could distort and even irreversibly deflect the Christian understanding of the relationship between God and humanity. If this would happen humanity will be capable of proclaiming its own independence from God thus "deifying" itself and the whole created universe. In this, the existential communion with God will 
be lost and the whole of the human creativity will become deviated from its originary set true soteriological telos. Christianity, as a social phenomenon, could remain exercising its normative practice, in particular justifying and judging other non-Christian activities. However the broken unity of knowledge of the world in God and God in the world, within humanity inevitably leads to polarisation between secular knowledge and theology. Secularism becomes manifest exactly as a consequence of the excess in the degree of changing the tropos of its nature (resulting in a change of anthropology) with respect to its logos. Said bluntly, secularism emerges as the inevitable consequence of the deficient anthropology. Deficient anthropology transforms theological ontology of existence into onto-theology (that is metaphysical theology devoid of any existential meaning): the Revelation and communion become to function as ontotheological notions (as artefacts of non-existential discourse), devoid of existential meaning and eucharistically sacramental character. Theology as experience of God becomes detached from secular creativity, so that, de facto, creativity within Christianity becomes impossible. Hence any project of Christian culture or science seems to be existentially viable as explicitly opposed to secularism.

Here we face a problem of how to reconcile the appropriation of the modern secular scientific culture by Christianity keeping its fidelity to what is called tradition. Tradition, in theology, means first of all that theology is not an ingenious accomplishment of an individual religious philosopher, and it is not a simple cumulative result of generations of religious meditation; it is the integrity of religious experience within the Church, its intrinsic Catholicity, which is affirmed through the interaction of the human spirit with the Spirit of God. For theology tradition is not only "repetition" of those religious events which are commemorated liturgically, it is not only reciting the texts and passive reading of the Fathers of the Church. It is rather the process of the constant invocation of the presence of the Spirit of God in the Church and the world, the invocation which (in its uniformity with the past), carries out an ontological element of a never-ending hypostasization of the reality of the Church as well as its theology. In this sense tradition can be understood beyond the famous dichotomy between sedimentation and innovation. Being a living tradition it is an evolving tradition: it faces challenges from the evolving humanity which sometimes is driven by unintentional and impersonal dramatic urges, related to society its politics, culture and science. It is in this sense that the presence of tradition is a constant reminder that human subjectivity should involve itself in its own re-assessment through positioning itself in tradition. However, what is popularly called the renewal or revival of tradition is not an exit from this tradition, it is rather a critical and nonaccomodating acquisition of new ideas within the same tradition, but in the context of the present age. It is through the efficacy of the past in the present of religious experience, that theology cannot take the arbitrary forms and developments which postmodern secular trends of thinking would like to promote. Theology remains that sphere of the human existence through which the secular processes can be mediated, but not accommodated. The latter can be explicated through the radical stance on secular culture and science following from the requirement that ecclesial theology must draw a clear borderline between the dispassionate contemplation of what happens in modern culture and science and its involvement in it. By not accommodating secular culture and science, ecclesial and hence traditionimbued theology is endowed with the right to judge the secular world through its consistent and permanent critique. However, its radical critique 
of the scientifically asserted world does not preclude this same theology from being radically positive with respect to science and the world. What Orthodox theology judges is the alleged autonomy and independence of the scientific view of the world from its very intricate inherence in the human and hence in the Divine (C.f. Nellas 1997, pp. 93-104). By so doing theology speaks of something which is not God, but it recognises a clear difference in this speaking. The positive judgement of science and the world as distinct from Christianity and God originates from the sanctification which existential ecclesial theology undertakes by bringing all fruits of human labour, including science and its picture of the world, to the their correct operation in the wholeness of communion.

It is imperative to discern which new insights in the history of ideas must be embraced and addressed by Christian theology. The creative activity which led to the rise of western secular culture has always been recognised and mediated by the Christian tradition: "Theology today must remain open to embrace both humanity and the cosmos; it must take into account both the aspirations of all mankind and the results of modern science and technology" (Staniloae 1980, pp. 224, 226). Creativity which is manifested through scientific research and cultural activity, in fact represents a permanent task of the Church itself. The tradition of the Church is living and evolving, for Orthodoxy, in a proper sense of this term, is itself an infinite task. Correspondingly Orthodoxy implies transmission through overcoming a dichotomy between sedimentation and innovation in the core of human history, theologically understood as synergy between man and God along the promised telos of salvation. It is faithfulness to tradition which balances the unrestrained urges for innovation and unnoticed slide to secularism that discerns the danger of making socially optimistic claims while amending and "accomplishing" theology in the present age. If innovation is a tendency, it has an open-ended character and thus its sense can only be grasped in the perspective of the age to come. Realised eschatology ordains realised innovation. In this sense all innovations implied by the NeoPatristic Synthesis have sense only through their constant Eucharistic re-assessment. It is in this sense that the truth of secular culture and science can only be assessed through assigning them a para-eucharistic modality, that is restoring them to a proper status in communion. ${ }^{44}$

If innovation is seen as a thing in itself devoid of its own theological critique, it can lead to a destructive utopianism. Those philosophers and theologians who criticise science and technology, confess a nostalgia with respect to "security" and "assurance" in that pre-technological state of affairs in the world which, as it is believed, had been more stable and peaceful, which was not threatened by ecological problems and possible technological disasters, and in which the world seemed to be unchangeable and "eternal". However, the paradox which is present in this vision is that history itself is abolished because it looses the sense of direction and the goal. The very nostalgic attempt to diminish and ignore the impact of modern science and technology represents an a-historical delusion which, de facto, denies the intrinsic teleology which drives science and technology and which ultimately has a human origin. On the other hand, one must admit that scientists, who promote technological progress, themselves do not understand the goals, not saying at all an eschatological meaning of technology. ${ }^{45}$ The fear of any teleological connotation in modern science and technology originating in secular presuppositions of scientists creates an obstacle to the sense of eschatological presence revealed through exploration of the world and fusion of humanity with the world as its continuing embodiment in it in the conditions 
of communion with God. ${ }^{46}$ In view of this the objective of Christian theology is not to criticise and judge science, but to reveal and revive in its development that sought eschatological presence which will allow a Christian to rethink the meaning of the ambivalence of science and technology in human life, as a mode of suffering, as that struggle for the Divine love, which is always open to humanity in the perspective of the age to come. For an Orthodox Christian, science and technology is that cross of hardship, doubts and contradictions, which one has to carry in order to achieve the perception of the eschatological presence in the passage of modern life.

It follows from what we have just discussed that eschatologism implies transcendence, but not in a sense of futurology (or futuristics), as prognostics of the future from the given present, but as remembrance of the future, or, conversely, anticipation of the past, by seeing things not through a natural passage of time, but through an anxious expectation of the age to come from where the sense of things, their purposes and ends will shine through. This, using the words of D. Staniloae, "demonstrates that we cannot understand nature and the meaning of science and technology without recognising a high human destiny, the calling of man to find his fulfilment in God" (Staniloae 1980, p. 225) ${ }^{47}$. It is this destiny which safeguards man against all fears of technology: "It is called upon to deliver man from the feeling that he is crushed by technology, just as the Gospel and the teaching of the Fathers delivered him from the feeling that he was at the discretion of certain capricious spiritual beings who made use of nature in an arbitrary way" (Staniloae 1980, p. 225). P. M. Gregorios expressed a similar thought, while reflecting upon patristic heritage: "Man who exercises lordship over creation without reference to his communion with God and to his contingent existence dependent upon God as Creator, is distorted man...Man is not master of the world of his own. He can become truly master of the creation only by being related to the Creator as image of manifest presence. This means that we will need to develop a "science" and "technology" that will keep our relationship with the other pole of our existence - with our Creator and our archetype, God" (Gregorios 1988, p. 225).

Thus one can suggest that technology must be appropriated by Christianity in a different way by subjecting technological development and the alternative futures it suggests to the scrutiny of the transforming presence of the age to come. It is exactly this presence that is missing in all sorts of "end-of-the-world" eschatologies. The eschatological transformation of the attitude to technology implies the transformation of perception of time such that time is not seen any more as unfolding from the past through its branching into alternative futures and carrying with itself all inevitabilities of the present human conditions and lost hopes for physical survival, but, on the contrary, that perception of time which comes from the eschaton, so that the very contemplation of the past is seen now as the specific and concrete anticipation of the future age along the lines of the infinite tasks of humanity. This means that science and technology must be turned towards their proper place in the infinite tasks of humanity and its destiny, rather than to be treated as a part of the process of gradual self-subjugation and adaptation to the necessities of nature (although in its technological extensions). Then and only then the existing schism between theology and science can be overcome by reverting its roots from the historical past, which is haunted by hostility and suspicion, to the common telos of theology and science which is inherently present in the core of the human condition and which drives science and theology to the realisation of the destiny of humanity. 
The realised eschatology of the sciencereligion dialogue (as realised innovation) directs attention not so much to the origin of things in the past of the universe and human history, but appeals to treat the origins of things through the telos of their explanation, which points towards the age to come. For example, one can be fixed on the idea that there was an evolutionary beginning of all humankind which could potentially "explain" the facticity of the human race. However, by approaching this origin through the humble heart, one could see that phenomenality of this origin will never be disclosed fully to us, but whose incessant presence in our quest for the mystery of our existence, will always form a telos of all explanations in an attempt to understand humanity's destiny. A similar thing can be said about the origin of the universe: the so called Big Bang, which is usually depicted as something physically real in the past of the universe, in fact, functions in human consciousness as a telos of all cosmological explanations. ${ }^{48}$ Cosmology, incapable of explaining the contingency and facticity of the present universe attempts to explain it away by extrapolating all forms of matter and things in the universe back in time to the singular undifferentiated state in which "all was in all", and claims that this primordial, although nonphenomenal "being", was allegedly responsible for the facticity of everything in the world. However a spiritually attentive intellect directs one to a different treatment of the origins of the universe by pointing out that the comprehension of its givenness through remote consequences is always to be attempted through the movement of the human knowledge to the future, through the anticipation of the allegedly existent past in the telos of all explanations. It is in this theological sense that cosmology looses its sense of an archaeology of the physical universe and acquires more the features of archaeology of the human spirit searching for the ground of its own facticity. ${ }^{49}$ What happens here is the combination of our desire to commemorate the past origin of the universe ( $\alpha v \alpha$ ó $\mu v \eta \sigma ı)$ ) through scientific exploration, with the invocation of the age to

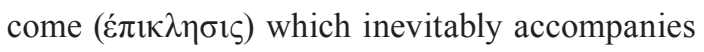
that commemoration if it attempts to unfold the mystery of our existence and our destiny in the context of realised eschatological presence..$^{50}$ Thus remembrance, past and history are not abolished but rather defined through the invocation of the Holy Spirit which is always an eschatological act. It is here that we see the presence of an intrinsic eucharistic ethos in all modalities of science whose unfolding in history is driven by its hidden telos, whose meaning cannot be known directly, but whose eschatological presence is achieved every time that one invokes the questions about our ultimate origin and destiny. Thus the end of time for which all hope, determines the origin, but not vice versa.

\section{Conclusion}

The contemporary state of affairs in an academic and wider social reality demands that the dialogue between theology and science takes a more radical form aiming to fight the militant atheism and secularism which exploit and misuse results of scientific progress. The radical theological commitment asserts that the dialogue between theology and science cannot be symmetric and assumes the existence of theological meta-narrative having capacity for critical assessment of modern science. The question of the relevance of the Church tradition and its wisdom in the dialogue with science becomes effectively an apology for their survival in the economically and politically dominated society. The Neo-Patristic legacy of G. Florovsky is considered as contributing to the metanarrative of theology and the task of a defence of Christian values, acquiring a radical dimension of critique of secular culture and science in particular. 
It characteristically bases its stance on the relevance of experience of God by the Fathers of the early Church, by advocating the restoration of the Divine-given dignity in humanity through communion with God transcending the scope of the natural theology. Any tension between theology and science is destined to disappear if they both are seen as flourishing from the same human experience of existence-communion. Science thus cannot be detached from theology and it is in a complex with theology that it can be properly understood and treated. One sees thus that the communal (liturgical) dimension of Greek Patristic synthesis provides us with another methodological rule of mediation between theology and science, namely that this mediation can never be detached from experience of the living God in ecclesial communities. The mediation between theology and science itself thus acquires the features of ecclesial activity.
The radicalness of the proposed approach to the dialogue can be supported by the conviction that neither the doctrine of creation nor the doctrine of the Incarnation can allow theology to detach itself from the natural or human sciences studying humanity as set by God to the task of exploring and bringing to word, the order and harmony of the universe. Science regarded this way appears to be a part of humanity's religious duty, as part of its faithful response to the Creator and Sustainer of the Cosmos. Humanity thus exercises communion with the universe through a para-eucharistic employment of science thus contributing to the mediation between theology and science.

\section{Acknowledgement}

I am grateful George Horton for reading the manuscript and some useful suggestions on how to improve its style.

On an Orthodox Christian appropriation of existentialism see (Puhalo 2001, pp. 48-59).

Atheism constitutes an indispensible aspect of modern social reality in that part of the human community, which is associated with the cumulative symbol of the "West". To be more precise, atheism enters the definitional characteristic of the West together with such terms as secularism and nihilism. All together these terms aim to imply that all aspects of the traditional Christian life, its values and ideas become practically non-observable and carefully hidden under the surface of the politically correct ideologies. Any talk about belonging to Christianity is encouraged only on the level of private life, so that Christian values are not taught and explained in public schools and universities. One means here not only the lack of systematic theological education (not Religious Studies) in schools, but a complete hostility and suspicion with respect to anything religious, and hence fideistic in some academic circles (both in the West and the East). While the militant scientific atheism is no more in place in the traditionally Orthodox countries as being ideologically discredited in the recent part, what replaces it is its transformed and socially adjusted remnant, a relict tail of the atheistic form of consciousness, which can be labelled as secularism. Atheism also means a certain stance on the nature of reality and its knowability. Orthodox theology asserts that reality, understood in a wide theological sense, is much wider than that which is known to human beings through scientific research. If the human reason is subjected to this lure of all-embracing knowledge, and disregards the human spiritual experience of contemplating realities which are beyond the visible and intellectual, it inevitably arrives at the idol of scientific progress which can only know this reality outwardly, and manipulate it technologically: "We have become so accustomed to the scientific-technological stance that we have lost the faculty of addressing reality as a whole, of seeing in it the source and sustainer of life, of responding to it with reverence and receptivity, and of surrendering ourselves to it in all fulfilling love. We have lost the capacity to respond with our whole being to the being of the Wholly Other who presents himself to us through the created universe" (Gregorios 1987, p. 91). See more details in (Nesteruk 2013, pp. 1-19).

See a more elaborate formulation of a mysticism of immanence, for example, in (Comte-Sponville 2006, pp. 145-212).

As was argued by G. Goutner, the alleged ideal of humanity, understood, for example as it unity, simply does not exist. One can think of it only in a modality of hope which has a religious nature (see (Goutner 2013, pp. 230-36)).

See examples of this in (Dawkins 2007), and (Stenger 2008).

See, for example, (Comte-Sponville, 2006).

This point was emphatically defended by C. Yannaras in his article "The Church in Post-Communist Europe" (Yannaras 2011, pp. 123-43). Yannaras gives a concise formulation of the consequences of such an ideology as it relates to existential dimensions of human persons: "Metaphysics, art, love, morality, are pushed to the margin of human life, as mere complements of "entertainment" or of psychological preferences, as an inactive "superstructure" on economic priorities that have been rendered absolute...".

9 This was the title of Ph. Sherrard's book The Rape of Man and Nature: An Enquiry into the Origins and Consequences of Modern Science (Sherrard 1991), where he aggressively criticised modern science for the exaggeration of the sphere of applicability of its methods and resulting dehumanisation of humanity and desanctification of nature. 
10 For futurological accounts based on the threats originating in modern science see books of (Leslie1996), (Rees 2003).

11 N. A. Berdyaev prophetically argued in the 1930s that humanity enters a new era when the stability of the world will depend on moral decisions of humanity of how to use technology available through scientific advance. See (Berdyaev 1991).

12 The negative attitude to technology can be traced back to a much deeper problem of Christianity and culture which has been in existence since the very emergence of Christianity in midst of the Hellenistic world. The historical lessons must be learned of how that ancient culture experienced creative transformation under the pressure of the sword of the Spirit dissecting this culture. For Christians, with all their suspicion and intrinsic hostility to the pagan culture of their time, it was a real challenge to exercise plasticity in order not to lapse to a pre-historical state, but to re-shape and transfigure "the cultural fabric in a new spirit" (see (Florovsky 1974, p. 25)). This is the reason why, by analogy, one can conjecture that in order not to lapse to the pre-technological utopian apology Christianity must exercise a similar plasticity in reshaping and transfiguring the modern scientific and technological culture in a similar spirit, that one which was used for the Christian critique and appropriation of Hellenism.

13 This is an expression from (Gregorios 1987, p. 100) (see also (Gregorios 1988, p. 225)). He qualified this fact with the lack of deepening our roots in the spiritual pole of our existence by more perceptive participation in the Community of the Spirit instead of strengthening the civilisation pole of our existence which diminishes and distorts that Community which lays in the foundations of all other realities (Gregorios 1988, pp. 225-26.) M. Heidegger long back in his "Letter on Humanism" expressed a similar thought about the lack of ability to transcend: "How can the human being at the present stage of the world history ask at all seriously and rigorously whether the god nears or withdraws, when he has above all neglected to think into the dimension in which alone that question can be asked? But this is the dimension of the holy, which indeed remains closed as a dimension if the open region of being is not cleared and its clearing is near to humans" (Heidegger 1998, p. 267).

14 P. M. Gregorios comments in this context "Science is not as objective a system of knowledge as we once thought it was. It is an option that we have chosen and which has given birth to the impressive reality of Western scientific-technological, urban-industrial civilisation. We are part of that system: it is our creation. We have chosen to limit our perception to the scientifically explicable, and despite the challenge of many phenomena which could have told us that there is something fundamentally wrong with the system we have gone ahead, hoping that all mysteries can be reduced to problems and puzzles soluble by intelligent conceptual investigation" (Gregorios 1987, p. 100 (emphasis added)).

15 As was expressed by R. Ingarden, "In transcending natural things [the products of human culture] lose the fullness and autonomy of existence, and do not have the force of a reality independent of man and his spiritual acts. These cultural products can gratify man's aspirations to a life elevated above nature only under the condition of his extraordinary spiritual activeness, and they fall back into total oblivion as soon as man looses the will to transcend his simple, inborn nature, and surrenders the creative activeness of his consciousness" (Ingarden 1983, p. 19).

16 Here we use the terminology from the novel Intermitencias da morte by a Nobel prize winner in literature Jose Saramago (see English translation (Saramago 2009)).

17 That is, "une avant-garde du prolétariat de l'humanité", in words of J.-L. Marion (Marion 2010, p. 25).

18 It is worth reminding the reader that what is generally known as the 'patristic' period corresponds to that historical era when fundamental Christian doctrines were fixed by the Fathers of the Church in a series of Church councils. The patristic period as understood within the Orthodox Christianity is often extended far beyond these 'official' historical limits until at least 14th century, the century of Gregory Palamas. In a sense, however, the patristic era never ended (see, e.g., (Ware 1997, p. 212)).

19 Georgyi Vasilievich Florovskyi (1893-1979) was one of the most influential Russian Orthodox theologians in the $20^{\text {th }}$ century, a philosopher and priest who had to emigrate from Russia after the revolution of 1917. A comprehensive account of life and work of G. Florovsky can be found in (Blane 1993). See also (Gavriluk 2015).

20 Typical examples of such schemes could be found, for example, in (Barbour 1990), and (Drees 1996).

${ }_{21}$ Independently of ecclesial theology phenomenology and existential philosophy, in their specific ways, were very sensitive to this issue. It is sufficient to remind one of Heidegger who insisted that the metaphysical God is an idea of God, in front of whom one cannot dance and to whom one cannot pray. Famously he claimed that a-theism, as the rejection of a god of metaphysics, was much closer to the dramatic perception of the living presence of God, than any sort of abstract philosophical theologising

22 It must be noticed here, however, that a neo-patristic synthesis does not pretend to build any accomplished and fixed anthropology, thus following a long tradition of the Christian East which never had any obligatory (to the faithful) system of views about man and cosmos. The Eastern theological attitude was very relaxed to the systems of knowledge based on secular science and philosophy, giving thus an unrestricted freedom in unveiling the human condition and abstaining from any attempt to treat the ever evolving debate about the human condition as the truth in the last instance (Zenkovsky 2005, p. 308). The intrinsic apophaticism toward anthropology guaranteed freedom to science and philosophy to express views about humanity without exhausting them entirely. The major stance of Christianity about the divine image in man can only be commented and supplemented by advances in science and philosophy, but it can never be abolished and reduced to any fixed conceptual expression.

23 "Our contemporary world, atheistic and ridden with unbelief, is it not comparable in a sense with that pre-Christian world, renewed with all the same interweaving of false religious trends, sceptical and anti-God? In the face of such a world, theology must all the more become again a witness. The theological system cannot be a mere product of erudition, it cannot be born of philosophical reflection alone. It needs also the experience of prayer, spiritual concentration, pastoral solicitude" (Florovsky 1975[1], p. 207).

24 See the development of this term in (Meyendorf 1978). 
25 In Maximus' words to carry out the divine will means to have understanding of divine wisdom and through the holy way of life to make oneself fit to receive the Holy Spirit's indwelling and deifying presence. See First Century of Various Texts, 73 in The Philokalia vol. 2, p. 180.

26 One implies here not simply that all modern anthropology and psychology are de facto apophatic, for they deal not with living persons but only the signifiers of persons that never exhaust the sense of that what is signified, but theological recognition that human person is unknowable in principle because it carries a Divine image, that is an image of the unknowable. The classical example of this conviction can be found in Gregory of Nyssa's On the making of man, 11. See more on this issue (Marion 2005)

27 Here, in what concerns the development of theology, the thought of S. Bulgakov is indicative: “...One must clearly understand unavoidability of the dogmatic development in disclosure of the ecclesial self-consciousness, although its different expressions have only Church-historical origin and pragmatic character" (Bulgakov1991, p. 86). See also (Bulgakov 1937, p. 20). In this context it is interesting to quote J. Zizioulas, pointing to a delicate character of the possible renewal of the dogmatic content of faith: "There is a prevailing view among so called "conservative" Orthodox theologians that the doctrines of the Church constitute something "untouchable". This turns dogmas into petrified relics from the past and widens the chasm between the historical and eschatological perspectives of the continuity of the apostolic kerygma. A study of the early Church and an appreciation of the Eucharistic basis of doctrine, however, show that it is better to understand dogmas as doxological statements of the community as the "faith transmitted to the saints", constantly received and re-received by the consciousness of "community of the saints" in new forms of experience and with a constant openness to the future" (J. Zizioulas, 1997, pp. 191-92).

28 This way one can overcome M. Heidegger's objection that one cannot speak of creation from any philosophical position which is neutral to faith. Heidegger claimed that a biblical response to the metaphysical question about the origin of existents is inappropriate. See, for example, (Heidegger 1959, p. 6-7). The Church Fathers, including those of Augusitine and Maximus the Confessor, understood quite well that the language of existents cannot be applied to the question of creation and that creation belongs to the liturgical usage from within which creation is acknowledged, established, that is constituted (see, for example, (Marion 2008, pp. 315-24)).

29 Maximus the Confessor, Ambigua 10 [PG91: 1113D].

30 The idea of makroanthropos developed by Maximus amount to that man becomes the world at large. It conveys the meaning that the world is called to be humanized, that is to bear the stamp of the human and to become-pan human. This notion also carries another important meaning, namely that, according to Maximus it is not man that is called to become "cosmosized"', but the whole cosmos to become humanized. The destiny of the cosmos is found in man, but not man's destiny in the cosmos. In this view it is the history of the universe becomes a part of the history of humanity, so that the cosmos is not only a mater of theoretical investigation, but the medium of the human existence servicing it in a practical way.

31 The Greek usage of the term logos in the context of human nature means the underlying and forming principle of humanity, that immanent and transcendent foundation which justifies the contingent facticity of every creature.

32 The term tropos, in contradistinction with logos, signifies a mode or a way of existence within the givenness of the logos, the latter being the principle of this existence.

33 One implies here that abuse of science as misuse of creation which have been characterized in Orthodox literature as diminution of humanity, dehumanization of nature and its desanctification (see, for example, (Sherrard 1991)).

34 The sphere of operation of theological critical thinking is in all realms where the Church (ecclesial humanity) meets historical and cultural reality. Theology creatively and critically thinks of any emerging historical problem or scientific theme, while remaining in the immutable state of the Church's spiritual life, because this life is experience of God, that is, of eternity In words of D. Staniloae: "The very existence of the Church is an effect, continually renewed of the action of the Holy Spirit in creating communion" "The door of the infinite riches of the personal or interpersonal divine being has opened up before the reflections of Orthodox theology, and with it the prospects of an endless progress of the human spirit within the divine" (Staniloae 1980, p. 218). Analogously Metropolitan Filaret describes the paradox of the Church mission in 'this world' as "that the power of the ecclesial influence of the world directly depends on the ability of the Church to be 'bigger than the word', to transcend the world and to see it through the 'Divine vision' " (Filaret 2004, p. 53). Thus theology always functions from above mass-religious consciousness, as well as "secular" scientific consciousness which claims its freedom from any faith commitments; theology's unceasing task is to provide a constant and constructive critique of these modes of consciousness by referring them to the original divine image in humanity.

35 Gregory the Theologian, Oration, XXVIII, 29. This English translation is from (Norris 1991, p. 242).

36 Clement of Alexandria, The Stromatata, or Miscellanies, Book I, Ch. 5 (abbr. Strom., I, 5) [English translation is from: ANF, vol. 2].

37 V. Lossky rephrased this thought: "Christian theology is able to accommodate itself very easily to any scientific theory of the universe, provided that this does not attempt to go beyond its own boundaries and begins impertinently to deny things which are outside its own field of vision" (Lossky 1957, p. 106).

38 The notion of the logoi which were extensively developed in theology of Maximus the Confessor in the VI century, can be also found in the Church writes before him. For example in Gregory the Theologian Orations XXVIII,16; XXX.20; XXXII.7, XLIII.67; in Gregory of Nyssa On the Making of Man, 24; in Basil the Great, The Hexaemeron, I:7-8; in Dionysisus the Areopagite, The Divine Names, V:7-8; in Evagrius Ponticus, The Prakticos, 92. The concept of the "seminal reasons", similar to the logoi was also developed by St. Augustine of Hippo.

39 On Maximus' theory of the logoi see e.g. (Thunberg 1995, pp. 64-79) and (Thunberg 1985, pp. 134- 143). See also (Balthasar 2003), as well as (Larchet 1996).

40 One should mention, however that the natural contemplation which Maximus used for description of knowledge of the logoi in their unity, which provides an access to the Logos of God, being organically a sort of communion with God, as- 
sumes that the Holy Spirit is present in this communion. This means that God opens His mystery only to those who do not speculate abstractly about the high being and origin of the world, but for whom the communion through the works of the Logos is accompanied by the communion through Scripture, as well as by the sacramental communion with Christ.

${ }_{41}$ Maximus the Confessor, Ambigua, 22 [PG 1257 A] [This English translation from French ((Riou 1973, p. 60)) is by L. Thunberg (Thunberg 1985, p. 140)].

42 See (Thunberg 1995, p. 397). The term "cosmic liturgy" appeared in the title of Balthasar's book (Balthasar 2003). See an interesting accentuation of this motive in (Crétien 2004, ch. 5).

43 Theology asserts itself as a meta-discourse, that is, as that form of critical thinking about different modalities of social activity, including a scientific one, which expresses the Divine presence and action, and which is not being bounded or exploited by some other particular human activities as their "prophetic" voice, be it the socio-historical sciences or a kind of all-encompassing transcendental philosophy. The critical function of theology with respect to other discourses never allows theology to slip into such a position that its scope and place will be determined by other discourses, for example by the science-religion dialogue as such. In this sense theology can never be defined and positioned by secular reason and thus it does not accept the idea of a complete autonomy of that sphere of the worldly reality which is asserted through rational, that is scientific, understanding. As it is emphatically advocated by J.-L. Marion, theology deals with the saturated phenomena, whose phenomenality cannot be embraced by means of scientific analysis.

${ }_{44}$ Compare with a characteristic quotation from J. Zizioulas: "Science and theology for a long time seemed to be in search of different sorts of truth, as if there were not one truth in existence as a whole. This resulted from making truth subject to the dichotomy between the transcendent and the immanent, and in the final analysis from the fact that the "theological" truth and the "scientific" truth were both disconnected from the idea of communion, and were considered in terms of a subject-object framework which was simply the methodology of analytical research .... If theology creatively uses the Greek patristic synthesis concerning truth and communion and applies it courageously to the sphere of the Church, the split between the Church and science can be overcome. The scientist who is a Church member will be able to recognize that he is carrying out a para-eucharistic work, and this may lead to the freeing of nature from its subjection beneath the hands of modern technological man" (Zizioulas 1997, pp. 119-120).

45 See in this respect a classical paper of M. Heidegger "The Question Concerning Technology" (Heidegger 1977, pp. 3-35). There are some other overtones of this discussion as to whether technology threatens with the overcoming our humanity: see, for example, (Janicaud 2005).

46 The tragic aspect of being a Christian is to perceive constantly the eschatological presence in the natural conditions where life wants to be happy and comfortable. In a way the very essence of that eschatological presence is to remind us constantly that the goal of our earthly existence is not here and now, not even tomorrow but in the future age. Past, present and what we call stability of tomorrow have meaning in so far they are seen in the perspective of the age to come. All human lives in their contingent historical incarnation can have some deep sense from the perspective of the future. If we "..being Christians prefer the confidence, reliability and security, all these things turn out to be mere illusions and obstacles to the eschatological presence" (Athanasios 2005, p. 61).

47 Compare with (Clément 1976, pp. 129-130).

48 See a detailed discussion in (Nesteruk 2015, pp. 334-343, 372-401).

49 C.f. with a similar stance on the sense of cosmology as disclosed from within human history as thus being the derivative of the latter in (Clément 1976, pp. 80-81).

50 This situation in modern understanding is similar to that ambivalence which conditioned the thought of the Fathers of the Church who used categories applicable to this world (such as "remembrance") in order to express their perception of the age to come: "remembrance of the future". The culmination of this ethos of the Church as being existence in history but not of history takes place in the celebration of the Liturgy in the invocation of the Kingdom in the anaphora: "Bearing in remembrance, therefore, this commandment of salvation, and all those things which came to pass for us; the Cross, the Grave, the Resurrection on the third day, the Ascension into Heaven, the Sitting on the right hand, the Second and glorious Coming again" (Liturgy of St. John. Chrysostom). Here the suspension of ordinary temporal order takes place which expresses in terms as they are available to humanity the presence of the future age. Contemporary cosmology which unconsciously follows a similar path of anticipation of the pre-temporal past makes effectively a liturgical act of invoking the future age of knowledge of the universe, from which the past and present of the universe will be seen not in sense of construction but rather in a sense of dilation between two parentheses which manifest the alpha and omega of human existence.

\section{Bibliography}

\section{Abbreviations}

PG: ed. J. P. Migne, Patrologia Graeca, 161 vols. (Paris, 1857-66).

ANF: The Ante-Nicene Fathers, vol. 2, (Grand Rapids, MI: W.B.Eerdman Publishing Company, 1962).

The Philokalia: St. Nikodimos of the Holy Mountain and St. Makarios of Corinth. The Philokalia:

The Complete Text, 4 vols., ed. G. E. H. Palmer, P. Sherrard, and K. Ware (London: Faber, 1979-95). 


\section{Patristic writers}

Basil the Great, The Hexaemeron.

Clement of Alexandria, The Stromatata, or Miscellanies.

Dionysisus the Areopagite, The Divine Names.

Evagrius Ponticus, The Prakticos.

Gregory of Nyssa, On the Making of Man.

Gregory the Theologian (Nazianzus), Orations.

Maximus the Confessor, Ambigua.

Maximus the Confessor, Centuries of Various Texts (in The Philokalia), vol. 2.

\section{References}

Athanasios, Metropolitan of Herzegovina,(2005) "Eschatology in our Everyday Life", in Orthodoxy in the Modern World (St. Petersburg, Aletheia, 2005): 52-61 (In Russian: Афанасий, Митрополит Герцеговины, Эсхатология в нашей повседневной жизни//Православие в современном мире, СПб: Алетея, 2005, с. 52-61).

Balthasar, H. Urs von (2003), Cosmic Liturgy. The Universe according to Maximus the Confessor (San Francisco: Ignatius Press, 2003).

Barbour, I., G. (1990), Religion in an Age of Science (San Francisco: Harper \& Row, 1990).

Berdyaev, N. (1944), Slavery and Freedom (London: Centenary, 1944).

Berdyaev, N. (1991), “Man and Machine”, Issues in Philosophy (Voprosy Filosofii) 8 (1991): 14762 (in Russian: Н. Бердяев, Человек и машина//Вопросы философии, 8 (1991), с. 147-162).

Blane, A., (1993) (ed.), Georges Florovsky. Russian Intellectual and Orthodox Churchma (NY: St. Vladimir's Seminary Press, 1993).

Bulgakov, S. (1937), "Dogma and Dogmatics", in The Living Tradition. Orthodoxy in the Modern World (Paris: YMKA-Press, 1937): 20-27 (in Russian: С. Булгаков, Догма и догматика, в Живое предание. Православие в современном мире. Париж: YMCA-Press, 1937, cc. 20-27).

Bulgakov, S. (1991), Orthodoxy. Elements of Teaching of Orthodox Church (Moscow: Terra, 1991) (in Russian: С. Булгаков, Православие. Элементы учения Православной Церкви. М.: Терра, 1991).

Bulgakov, S. (1999), "Social Teaching in Modern Russian Orthodox Theology" in S. Bulgakov, Towards a Russian Political Theology, ed. and intr. Rowan Williams (Edinburgh: T\&T Clark, 1999): 269-292.

Bulgakov, S.(2002), The Bride of the Lamb (MI: Grand Rapids, 2002).

Clément, O. (1976), Le Christ Terre des Vivants. Essais Théologiques Spiritualite Orientale, n. 17, (Bégrolles-en-Mauges: Abbaye de Bellfontaine, 1976).

Cretien, J.-L. (2004), The Ark of Speech (London: Routledge, 2004).

Comte-Sponville, A. (2006), L'esprit de l'athéisme. Introduction à une spiritualité sans Dieu (Paris: Albin Michel, 2006).

Dawkins, R.(2007), The God Delusion (London: Black Swan, 2007).

Drees, W., B. (1996), “A 3 X 3 Classification of Science-and-Religion”, Studies in Science and Theology 4 (1996): 18-32.

Filaret, Metropoplitan of Minsk and Slutsk (2004), The way of the life-asserting love (Kiev: Duh I Litera, 2004) (in Russian: Митрополит Минский и Слуцкий Филарет, Путем жизнеутверждающей любви, Киев: Дух и литера, 2004). 
Florovsky, G. (1961), "The Quest for Christian Unity and the Orthodox Church", Theology and Life 4 (1961): 197-208.

Florovsky, G. (1972 [1]), “The Lost Scriptural Mind”, in Bible, Church, Tradition: An Eastern Orthodox View. Collected Works of Georges Florovsky, vol. 1 (Belmont, Mass: Nordland, 1972): 9-16.

Florovsky, G. (1972 [2]), "The Catholicity and the Church", in Bible, Church, Tradition: An Eastern Orthodox View (Belmont, MA: Nordland, 1972): 37-55.

Florovsky, G. (1972 [3]), "St. Gregory Palamas and the Tradition of the Fathers", In Bible, Church, Tradition: An Eastern Orthodox View (Belmont, Mass: Nordland, 1972): 105-120.

Florovsky, G. (1974), "Faith and Culture", in Christianity and Culture . Collected Works of Georges Florovsky, vol. 2 (Belmont, MA: Nordland, 1974): 9-30.

Florovsky, G. (1975[1]), "The ways of Russian Theology", in Aspects of Church History, in Collected Works of Georges Florovsky, vol. 4 (Belmont, MA: Nordland, 1975): 183-209.

Florovsky, G. (1975[2], "Patristic Theology and The Ethos of the Orthodox Church", in Aspects of Church History, (vol 4. in the Collected Works) (Belmont, Mass: Nordland, 1975): 11-30.

Gavriluk, P. (2015), George Florovsky and the Russian Religious Renaissance (Oxford: Oxford University Press, 2015).

Goutner, G. (2013), “The Unity of Humanity in an Eschatological Perspective." In Theology of Creation, ed. A. Bodrov, M. Tolstoluzhenko, (Moscow: St. Andrew's Biblical and Theological Institute, 2013): 230-236 (in Russian: Г. Б. Гутнер, Единство человечества в эсхатологической перспективе// Богословие творения, под ред. А. Бодрова и М. Толстолуженко, М.: Изд-во ББИ, 2103, c. 230-236).

Gregorios, P. M. (1987), Human Presence. Ecological Spirituality and the Age of the Spirit (New York: Amity House, 1987).

Gregorios, P. M. (1988), Cosmic Man. The Divine Presence. The Theology of St. Gregory of Nyssa (New York: Paragon House, 1988).

Heidegger, M. (1959), Introduction to Metaphysics (New Haven: Yale University Press, 1959).

Heidegger, M. (1977), "The Question Concerning Technology" (in The Question Concerning Technology and Other Essays (NY and London: Garland Publishing, 1977).

Heidegger, M. (1998), "Letter on Humanism", in W. McNeill (ed.), Pathmarks (Cambridge: Cambridge University Press, 1998): 239-276.

Ingarden, R. (1983), Man and Value, (Washington, D.C.: Catholic University of America Press, 1983).

Janicaud, D. (2005), On the Human Condition (London: Routledge, 2005).

Larchet, J.-C. (1996), La Divinisation de l'homme selon Saint Maxime le Confesseur (Paris, Les

Editions du Cerf, 1996).

Leslie, J. (1996), The End of the World: The Science and Ethics of Human Extinction (NY: Routledge, 1996).

Llosa, M. V. (2011), “The Culture of Liberty”, The Morality of Capitalism (Students For Liberty and Atlas Economic Research Foundation, Ottawa, Illinois, Jameson Books, 2011): 114-122.

Lossky, V. (1957), Mystical Theology of the Eastern Church, (London: James Clarke, 1957).

Marion, J.-L. (2005), “Mihi magns quaesto factus sum: The Privilege of Unknowing”, The Journal of Religion 85, No 1 (2005): 1-24. 
Marion, J.-L. (2008), Au lieu de soi: L'approche de Saint Augustine (Paris: PUF, 2008).

Marion, J.-L. (2010), "La foi et la raison", Le croire pour le voir. Réflexions diverses sur la rationalité de la révélation et l'irrationalité de quelques croyants (Paris, Editions Parole et Silence, 2010): 17-29.

Meyendorf, J. (1978), Lilving Tradition. Orthodox Witness in the Contemporary World. (N.Y.: St. Vladimir's Seminary Press, 1978).

Nellas, P. (1997), Deification in Christ. Orthodox Persepectives on the Nature of the Human Person (Crestwood: St. Vladimir's Seminary Press, 1997).

Nesteruk, A. (2008), The Universe as Communion (London: T\&T Clark, 2008).

Nesteruk, A. V. (2013), "The Ecclesial Dimension in the Dialogue between Theology and Science", International Journal for the Study of the Christian Church 13, no. 3 (2013): 1-19.

Nesteruk, A. V. (2015), The Sense of the Universe (Minneapolils: Fortress Press, 2015).

Norris, F. W. (1991), Faith Gives Fullness to Reasoning. The Five Theological Orations of Gregory Nazianzen. Supplements to Vigilae Christianae, Vol. XIII (NY: E. J. Brill, 1991).

Puhalo, L. (2001), Freedom to Believe. Personhood and Freedom on Orthodox Christian Ontology (Dewdney, B.C., Synaxis Press, 2001).

Rees, M. (2003), Our Final Century, A Scientist's Warning: How Terror, Error, and Environmental Disaster Threaten Humankind's Future in This Century - On Earth and Beyond (London: W. Heinemann, 2003).

Riou, A. (1973), Le monde et l'eglise selon Maxime le Confesseur (Paris: Beauchesne, 1973).

Saramago, Jose (2009), Death with Interruptions (Boston: Mariner Books, 2009).

Staniloae, D. (1980), Theology and the Church (Crestwood, NY: St. Vladimir's Seminary Press, 1980).

Stenger, V. J. (2008), God the Failed Hypothesis: How Science Shows that God Does not Exist, (NY: Prometheus Books, 2008).

Sherrard, Ph. (1991), The Rape of Man and Nature: An Enquiry into the Origins and Consequences of Modern Science (Suffolk: Golgonooza, 1991).

Thunberg, L. (1985), Man and the Cosmos: The Vision of St. Maximus the Confessor (Crestwood, NY: St. Vladimir's Seminary Press, 1985).

Thunberg, L. (1995), Microcosm and Mediator: The Theological Anthropology of Maximus the Confessor (Chicago: Open Court, 1995).

Ware, K. (1997), The Orthodox Church (New York: Penguin, 1997).

Yannaras, C. (2011), “The Church in Post-Communist Europe”, in The Meaning of Reality. Essays on Existence and Communion, Eros and History (Los Angeles: Sebastian Press \& Indiktos, 2011).

Zenkovsky, V. (2005), "Our Epoch”, In Russian Thinkers and Europe, (Moscow: Respublika, 2005): 308-346 (in Russian: В. В. Зеньковский, Наша эпоха // Русские мыслители и Европа, М.: Республика, 2005, с. 308-346).

Zizioulas, J. (1997), Being as Communion (Crestwood NY: St. Vladimir's Seminary Press, 1997). 


\title{
От неопатристического наследия
}

\section{о. Георгия Флоровского \\ к радикальной богословской установке \\ в диалоге с наукой}

\author{
А.В. Нестерук \\ Университет Портсмута \\ Гэйт Бюлдинг, Лайон Террасса, Портсмут, \\ Великобритания
}

\begin{abstract}
Статья обсуждает возможные пути диалога между наукой и богословием в контексте современного атеизма и секуляризма. Проводится точка зрения, что такой диалог не может быть симметричным и что задачей богословской критики секуляризма является также критический анализ современных научных теорий в контексте экзистенциальных проблем как человечества в целом, так и каждой конкретной личности. В качестве исторической аналогии обсуждается идея неопатристического синтеза в богословии, предложенная в первой половине ХХ века известным русским философом и богословом о. Георгием Флоровским. Исследуются возможности расширения и развития идеи неопатристического синтеза на диалог между наукой и богословием. Выделяются основные моменты диалога, такие как проблема человеческой личности и примат жизненной веры как основания самой возможности научного творчества. В предлагаемой перспективе любые напряжения между богословием и наукой должны исчезнуть, если они рассматриваются как имеющие происхождение в едином и иеелостном человеческом опыте существования-сопричастия. В таком понимании наука не может быть отделена от богословия и только в комплексе с последним она может быть адекватно понята и интерпретирована.
\end{abstract}

Ключевые слова: атеизм, богословие, личность, наука, неопатристический синтез, диалог между наукой и богословием, познание, секуляризм, радикальная богословская установка.

Научная спеииальность: 10.00.00 - филологические науки. 